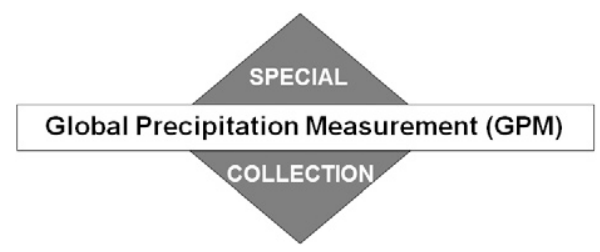

\title{
Ice Microphysical Properties near the Tops of Deep Convective Cores Implied by the GPM Dual-Frequency Radar Observations
}

\author{
XIANG Ni \\ Chongqing Jinfo Mountain Field Scientific Observation and Research Station for Kaster Ecosystem, School of \\ Geographical Sciences, Southwest University, Chongqing, China, and Department of Physical and \\ Environmental Sciences, Texas A\&M University-Corpus Christi, Corpus Christi, Texas
}

Chuntao LiU

Department of Physical and Environmental Sciences, Texas A\&M University-Corpus Christi, Corpus Christi, Texas

EDWARD ZIPSER

Department of Atmospheric Sciences, University of Utah, Salt Lake City, Utah

(Manuscript received 16 August 2018, in final form 23 May 2019)

\begin{abstract}
Using three years of observations from the Dual-Frequency Precipitation Radar (DPR) aboard the Global Precipitation Measurement (GPM) Core Observatory, properties of the cores of deep convection are examined. First, deep convective systems are selected, defined as GPM precipitation features with maximum 20-dBZ echo-top heights above $10 \mathrm{~km}$. The cores of deep convection are described by the profiles of $\mathrm{Ku}$ - and Ka-band radar reflectivity at the location of the highest echo top in each deep convective system. Then the dual-frequency ratio (DFR) profile is derived by subtracting Ka-band from Ku-band radar reflectivity. It is found that values of DFR are larger over land than over ocean in general near the top of the convection, which is consistent with larger ice particles in stronger updrafts in continental convection. The magnitude of DFR at $12 \mathrm{~km}$ is positively correlated with the convection intensity indicated by $20-$ and $30-\mathrm{dB} Z$ echo tops. The microphysical properties including volume-weighted mean diameter, ice water content, and total ice particle number concentration are derived using a simple lookup table approach. Under the same particle size distribution assumption, the cores of deep convection over land have larger ice particle size, higher ice water content, and lower particle concentration than those over ocean at levels above $10 \mathrm{~km}$, but with some distinct regional variations.
\end{abstract}

\section{Introduction}

Deep convection plays a crucial role in moisture and heat transfer in the tropics (Riehl and Malkus 1958), and is a key component in organized convective systems (Houze 1977, 2004; Houze et al. 2015; Zipser 1977). They are commonly found in various kinds of weather systems, such as squall lines, hurricanes, and monsoons (Xu and Zipser 2012; Jiang et al. 2011; Smull and Houze 1985). To quantify the role of the deep convection in latent heat release, it is important to understand the microphysical processes in the convective cores because they are directly related to the latent heat release and also related to

Corresponding author: Chuntao Liu, chuntao.liu@tamucc.edu the strength of vertical air motion in convective updrafts. Both numerical model simulations (e.g., Fierro et al. 2009) and field observations (e.g., Schumacher et al. 2007; Johnson 1984) have been attempted. In either case, it is recognized that the microphysical properties of the hydrometeors, especially ice particles in deep convection, have a large uncertainty and are still not fully understood (e.g., Varble et al. 2014). However, it is difficult to directly measure the properties of ice particles inside deep convection due to the harsh environment for in situ instruments, and for stronger storms, especially over land, flight safety considerations. Therefore, studies of microphysics inside deep convection have primarily relied on ground-based, airborne (e.g., G. M. Heymsfield et al. 2013, 2010), and spaceborne remote sensing observations. 
For example, microphysical evolution within cumulonimbus clouds in Florida have been extensively studied with ground-based radar in three-part studies by Yuter and Houze (1995a,b,c). Using multiple observational approaches, microphysical properties of hydrometeors (e.g., particle size distribution at different heights) in intense convection during the Midlatitude Continental Convective Cloud Experiment (MC3E; Jensen et al. 2016) were revealed during this campaign. These ground or airborne observations only infer the microphysical properties of deep convection from radar reflectivities at a local scale, but are not able to reveal the regional variations of microphysical properties from a global perspective.

As the first spaceborne precipitation radar, the Precipitation Radar (PR; operating at $\mathrm{Ku}$ band, $13.8 \mathrm{GHz}$ ) aboard the Tropical Rainfall Measuring Mission (TRMM) satellite has provided detailed perspectives of deep convection in various kinds of weather systems over different regions in the tropics and subtropics. Many studies summarize properties of deep convection and provided general pictures of characteristics of global deep convection, such as their locations (Zipser et al. 2006; Houze et al. 2015), sizes (Xu and Zipser 2012; Liu and Zipser 2013), rainfall intensity (Hamada et al. 2015), vertical structure (Zipser and Lutz 1994; Liu et al. 2007; Takahashi and Luo 2014), and latent heat release (Takayabu et al. 2010; Liu et al. 2015), over various regions (e.g., Sobel et al. 2004; Rasmussen et al. 2014; Houze et al. 2015). Following on the success of the TRMM, the CloudSat Cloud Profiling Radar (CPR; $94 \mathrm{GHz}$ radar), with the minimum detectable reflectivity as low as $-28 \mathrm{~dB} Z$, provides valuable information about the clouds associated with deep convection (Sassen et al. 2009; Luo et al. 2011; Xu and Zipser 2012; Yuan and Houze 2010; Takahashi and Luo 2014).

Building on success from the single-frequency PR and CPR, the new-generation Dual-Frequency Precipitation Radar (DPR) onboard the Global Precipitation Mission Core Observatory is designed to gain new insight into global precipitation as well as storm structures and mesoscale dynamics (Hou et al. 2014; SkofronickJackson et al. 2017). Using 1 year of observations, Liu and Zipser (2015) categorized convective systems by depth and intensity and extended the previous study of global intense thunderstorms (Zipser et al. 2006) to up to $65^{\circ}$ latitudes. With simultaneous observations of two radars at $\mathrm{Ku}$ and $\mathrm{Ka}$ band, DPR is capable to further infer the microphysical properties of hydrometeors inside the precipitation systems (Seto et al. 2013; Olson et al. 2016). Before the launch of GPM, dual-frequency retrieval algorithms have been reviewed and revised with hybrid methods (Le and Chandrasekar 2014).
Kuo et al. (2016) have discussed the microwave scattering properties of spherical ice-air particles and nonspherical snow particles based on the ice-phase particle model. It was also found that the rain and snow would be clearly separated on the $Z_{\mathrm{Ku}}-\mathrm{DFR}$ plane, which was confirmed by airborne observations (Liao and Meneghini 2011). These studies suggested a one to one correlation between characteristic diameters of ice particles and dual-frequency ratio (DFR) between Ku-band and Ka-band reflectivity values. Therefore, once the DFR in a volume with ice phase particles is known, it is possible to retrieve the mean diameter and other microphysical parameters in ice cloud with some assumptions. For regions inside strong deep convective cores, strong attenuation and multiple scattering of radar signals could make it difficult to derive microphysical properties (Battaglia et al. 2015, 2016). However, at high altitudes near the top of deep convection, these effects are much smaller. Also, updraft strength in deep convection shows general maxima above $10 \mathrm{~km}$ (G. M. Heymsfield et al. 2010). All these considerations make it possible and valuable to learn more about the ice microphysical properties near the top of convective cores using the GPM dualfrequency radars. Since the properties of hydrometeors near the top of convective cores are directly related to the strength of the convective updraft, this is an important step to understand the processes within deep convective clouds.

Deep convection widely occurs in different weather systems from hurricanes to mesoscale convective systems, to just single convection cells. With these very different occurrence environments, it is a challenge to reveal microphysical properties for all events. Here, we focus on the properties of convective cores, which would be defined as the pixel with the highest echo top. In this paper, 3 years of observations of GPM Ku-band and Ka-band radar data are examined together to advance our understanding of microphysical properties in the cores of deep convection. First, the regional variations of DFR and vertical structures of DFR profiles in the cores are examined globally. To further interpret these DFR values, a radar simulation package is utilized to estimate microphysical properties in the upper levels of the cores. In section 2, the dataset and radar simulation package are introduced. Climatologies and properties of DFR in the cores are described and discussed in section 3. Using the results of the radar reflectivity from the simulation package, the microphysical properties of ice particles in the upper levels of deep convection are derived and discussed in section 4. Last, discussion and summary are given in section 5 . 


\section{Data and methods}

\section{a. Satellite observations}

Three years of observations from April 2014 to March 2017 from DPR aboard the GPM Core Observatory are analyzed in this study. The DPR, as the first spaceborne dual-frequency precipitation radar, operates at $\mathrm{Ku}$ and $\mathrm{Ka}$ bands (13 and $35 \mathrm{GHz}$ ). The Ku-band Precipitation Radar (KuPR) and Ka-band Precipitation Radar (KaPR) both have 49 footprints in a single scan. The scan of the KaPR has two modes. The first KaPR scan mode is matched with the middle 25 footprints of the KuPR scan. Another mode takes observations between $\mathrm{Ku}$ scans with a high sensitivity. Further details of the DPR and corresponding instrument characteristics can be found in the overview of Hou et al. (2014). In this study, the most recent version 5 , matched $25 \mathrm{Ku}$ and Ka reflectivity profiles in the center of each scan are utilized.

To identify the deep convective cores, first, similarly to the definition of TRMM precipitation feature (PF; Liu et al. 2008), the GPM PFs are defined by grouping contiguous near-surface nonzero precipitation pixels within the matched swath. Then the properties of these precipitation features, including the size, location, echo tops, and others, are summarized for each PF. Among the millions of GPM PFs defined in the 3 years, we selected the PFs with the maximum 20-dBZ (Ku-band reflectivity) echo-top height (MAXHT20) higher than $10 \mathrm{~km}$ and having at least 10 surface raining pixels $\left(\sim 250 \mathrm{~km}^{2}\right)$. These selected PFs are regarded as deep convective systems. Then we define the pixel with the maximum 20-dB $Z$ echo-top height as a deep convective core (DCC). ${ }^{1}$ Then the $\mathrm{Ku}$ and Ka reflectivity profiles at the location of the maximum 20-dBZ echo top describe the properties of the DCC of each PF.

An example of a DCC, as defined in this paper, is shown in Fig. 1. In the vertical cross sections of $\mathrm{Ku}$ (Fig. 1) and Ka (Fig. 1b) radar reflectivity field, there are two convective cells with echo tops above $10 \mathrm{~km}$. The pixel indicated by the arrow is the one with the highest echo top and is defined as the DCC of this PF. The measured $\mathrm{Ku}$ and $\mathrm{Ka}$ reflectivity profiles of the DCC are plotted in Fig. 1 d. $\mathrm{Ku}$ and $\mathrm{Ka}$ reflectivity profiles are close to each other near the echo top. Then the differences between $\mathrm{Ku}$ and Ka reflectivities (DFRs) increase toward the lower altitudes (Fig. 1e). These differences

\footnotetext{
${ }^{1}$ This definition is analogous to, but different from, the DCC used in papers by the Houze group, for example, Houze et al. (2015), where DCC is the entire precipitation feature with $>30$ or $>40 \mathrm{dBZ}$ at $10 \mathrm{~km}$.
}

are partially due to the stronger Mie scattering of large ice particles at Ka band and partially due to the stronger radar signal attenuation at Ka band. In the DCCs, unless strongly tilted, radar reflectivity usually increases toward the surface at upper levels because it is difficult for large ice particles reach high altitudes due to a larger fall velocity. In Fig. 1d, both Ka and Ku reflectivity increase downward from 17 to $13 \mathrm{~km}$, where the Ka-band reflectivity reaches $35 \mathrm{~dB} Z$. The differences between the $\mathrm{Ku}$ and $\mathrm{Ka}$ reflectivity within this layer are mostly due to the different Mie scattering. However, below $12-13 \mathrm{~km}$, Ka reflectivity decreases toward the surface. In addition to the Mie scattering, the attenuation is significant; more so at lower altitudes. The measured Ku-band reflectivity increases up to $45 \mathrm{dBZ}$ around $5 \mathrm{~km}$ above the surface. This maximum $\mathrm{Ku}$ reflectivity near $5 \mathrm{~km}$ could be due to strong attenuation due to heavy rainfall below the freezing level. As a result of the differential attenuation at $\mathrm{Ka}$ and $\mathrm{Ku}$ bands, the DFR profile presents typical convective characteristics (Le and Chandrasekar 2014); increasing downward from the top of the DCC to the surface. The rapid decrease of DFR below $10 \mathrm{~km}$ is mostly caused by stronger attenuation at Ka band.

As shown in Fig. 1, there could be multiple echo-top peaks in each PF. To simplify the analysis, only profiles at the highest peak are used for each PF. Because each pixel is about $5 \mathrm{~km} \times 5 \mathrm{~km}$, which is most likely greater than a single updraft and downdraft size, here the DCC may contain both updrafts and downdrafts. The version $52 \mathrm{~A}$ algorithms for reflectivity attenuation correction utilize different lookup tables above and below the $-60^{\circ} \mathrm{C}$ level. Therefore, this may lead to unrealistic DFR values around $-60^{\circ} \mathrm{C}$ in deep reflectivity profiles, so we have chosen to use the measured reflectivity values in this study. The GPM KuPR has a sensitivity of about $12 \mathrm{dBZ}$ (Hamada and Takayabu 2016). The sensitivity of KaPR is still not well quantified. Although Toyoshima et al. (2015) found the best threshold to detect the storm top height is $18 \mathrm{dBZ}$ for $\mathrm{Ku}$ matched scan, the portion of reflectivity profiles less than $15(17) \mathrm{dBZ}$ at $\mathrm{Ku}(\mathrm{Ka})$ band are excluded in the analysis to increase sample volume. Using 3 years of observations, we have defined 54213 DCC globally, and 42403 of them are in the tropics $\left(20^{\circ} \mathrm{S}-20^{\circ} \mathrm{N}\right)$.

\section{b. Simulations to interpret the DFR}

Understanding the microphysical properties of precipitation is one of the most important goals of using dual-frequency radars in the GPM mission. Algorithms for deriving particle size distributions (PSDs) from spaceborne or airborne DPR observations have been developed since the design of the GPM Core Observatory (Rose and Chandrasekar 2006; Le and Chandrasekar 2014) and 

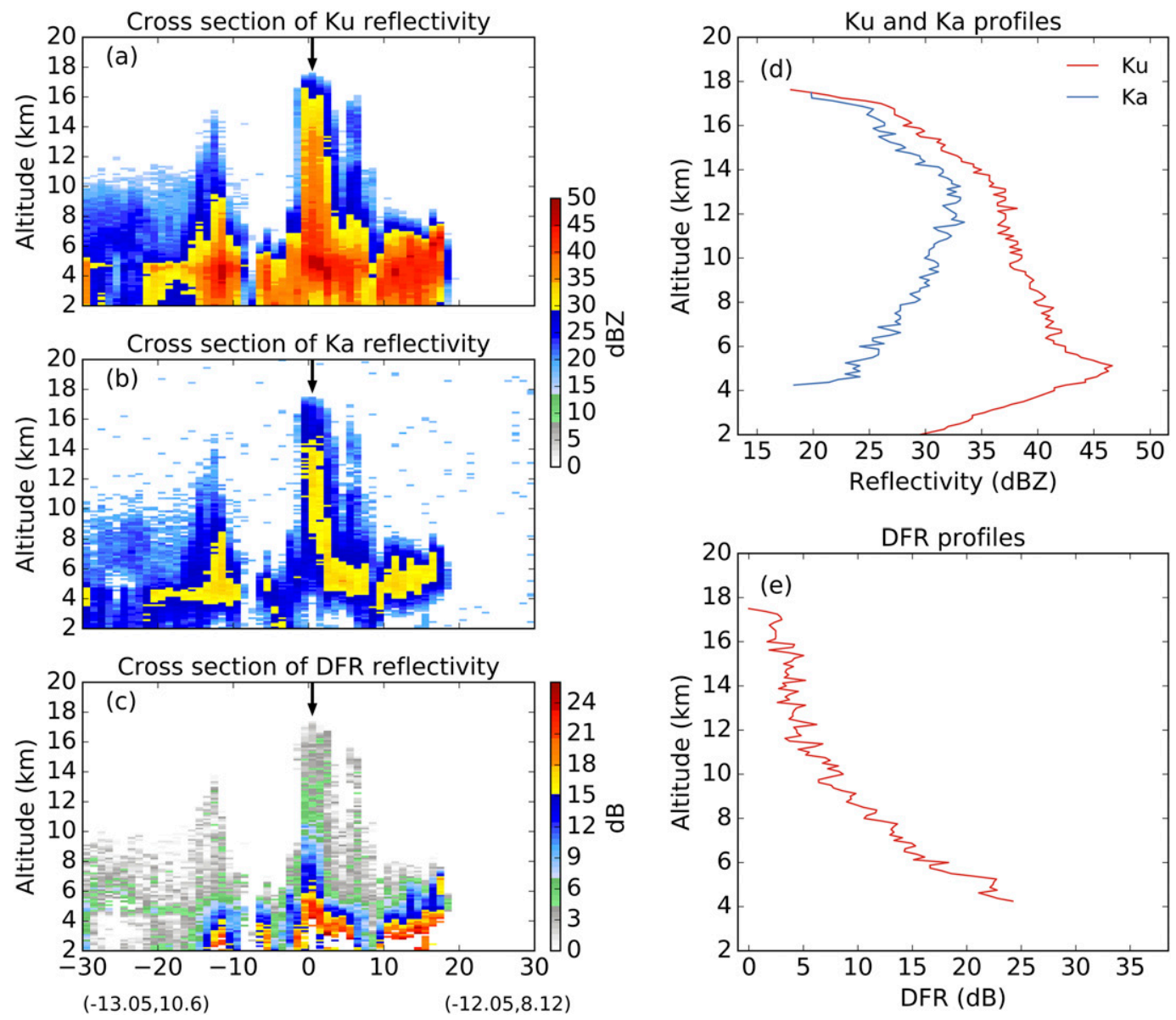

FIG. 1. An example of cross sections of GPM (a) Ku-band reflectivity, (b) Ka-band reflectivity, and (c) dualfrequency ratio (DFR) through a deep convective echo over the Sahel on 13 May 2015. The deep convective core (DCC) is selected at the column with the highest radar echo top as indicated by a black arrow in (a)-(c). Also shown are profiles of (d) $\mathrm{Ku}$ and Ka reflectivities and (e) DFR of the DCC.

are used to create the GPM product. The conventional algorithm based on analytical methods could estimate the PSD. However, the complex hydrometeor parameters lead to significant difficulties in the retrievals using dual-frequency radar observations. Therefore, lookup tables have been constructed to simplify the retrieval process (Liao et al. 2016; Olson et al. 2016). In this study, with a similar approach, we have constructed a simplified lookup table by using the radar simulation package named QuickBeam (Haynes et al. 2007). In consideration of the remote sensing properties of DCC, especially the DFR profiles in tropics, we used the QuickBeam to compute unattenuated radar reflectivity of volume with given ice water content (IWC) and mean diameter of spherical ice particles $D_{m}$. Brief setups of the simulation are depicted here with further details being available in the QuickBeam user's guide. The distribution of ice particles in the DCCs is assumed to be a modified gamma distribution as

$$
n(D)=N_{t} \frac{1}{\Gamma(\mu) D_{0}}\left(\frac{D}{D_{0}}\right)^{\mu+1} \exp \left(-\frac{D}{D_{0}}\right)
$$

where the distribution width $\mu$ is set as 2.0 and the characteristic diameter $D_{0}$ is calculated by

$$
D_{0}=\frac{\Gamma(\mu)}{\Gamma(\mu+1)} D_{m},
$$

where $N_{t}$ is the total particle number concentration, and $D_{m}$ is the volume-weighted mean diameter. The QuickBeam package follows the conventional approach and ice particles are assumed as spherical. However, the shape of an ice particle is crucial for the simulation results. Kuo et al. (2016) discussed scattering properties of falling snow and found that the Ku-/Ka-band backscattering efficiency of nonspherical crystals departs from the lines of size-dependent densities results when liquid equivalent diameter is greater than $1-1.5 \mathrm{~mm}$. The DFR 
between $\mathrm{Ku}$ and $\mathrm{Ka}$ bands is around $4 \mathrm{~dB}$ for $1.0-\mathrm{mm}$ snow particles when the $\mu$ is set to 2 (Kuo et al. 2016). Liao et al. (2016) examined the influence of shape parameter $\mu$ on DFR $-D_{m}$ and found that determination of $D_{m}$ is relatively insensitive to $\mu$. Therefore, in the modified gamma distribution, $\mu$ is set as a constant, 2 , in this study.

The standard tropical profiles of temperature and pressure in the QuickBeam package are utilized. To derive the reflectivity from space-based radar, we assume that the condensate consists entirely of spherical particles of ice at $10 \mathrm{~km}$. In the simulations, the nonattenuated reflectivity values at $\mathrm{Ku}$ and $\mathrm{Ka}$ bands are calculated using QuickBeam for ice particle size distributions with various IWC values ranging from $0.006 \mathrm{~g} \mathrm{~m}^{-3}$ (0.01 $\mathrm{mm})$ to $10 \mathrm{~g} \mathrm{~m}^{-3}(100 \mathrm{~mm})$ and $D_{m}$ values ranging from 0.1 to $100 \mathrm{~mm}$. The bins of IWC and $D_{m}$ are set in exponential intervals, and in total there are 420 IWC bins and $400 D_{m}$ bins. The total ice particle number $N$ is integrated using particle concentration output from a subroutine in the simulation package that creates discrete PSDs. After the calculations of reflectivity for given hydrometeor properties, the results are inversely interpolated to build lookup tables so that microphysical parameters, including $D_{m}$, IWC, and $N$, could be directly queried for given $\mathrm{Ku}$ reflectivity and $\mathrm{Ku}-\mathrm{Ka}$ DFR values.

In the simulation, the mass-dimension relationship significantly impacts the relationship between microphysical parameters, radar reflectivity, and backscattering efficiency (Kuo et al. 2016). Liao et al. (2016) found that the snow density influences the DFR $-D_{m}$ relationship most. A. J. Heymsfield et al. (2010) constructed a mass-dimension relationship based on observations of natural ice clouds at temperatures from $0^{\circ}$ to $-60^{\circ} \mathrm{C}$. This mass-dimension relationship is found to be consistent with the simulated particle's mass of individual crystals in simulation of pristine ice crystals (Kuo et al. 2016) and also is close to the environments of deep convection studied in this paper. Therefore, in the QuickBeam setup we used the Heymsfield's mass-dimension relationship as

$$
m=a D^{b},
$$

with $a$ and $b$ set as 0.0110 and 2.1 in cgs units. These specific parameters are derived from 12 convective cases over or offshore of West Africa during the National Aeronautics and Space Administration (NASA) African Monsoon Multidisciplinary Analyses (NAMMA) field campaign (A. J. Heymsfield et al. 2010; Zipser et al. 2009). The uncertainty of these assumptions in the calculation is discussed in section $4 \mathrm{c}$.

\section{Properties of deep convective cores}

\section{a. Ku and Ka radar reflectivity profiles}

The global distribution of population of DCCs in $2^{\circ} \times$ $2^{\circ}$ grid boxes is shown in Fig. 2a. The DCCs are mostly found over a few hot spots, including the Maritime Continent, central Africa, Amazon, and Central America, which is consistent with previous studies of deep convection (Zipser et al. 2006; Liu and Zipser 2015). Although most of the hot spots are located over land, the total number of DCCs is greater over ocean (28454 DCCs) than over land (25759 DCCs).

The median values of DFR at $12 \mathrm{~km}$ from these DCCs are calculated in each grid and shown in Fig. 2b. A higher value of DFR indicates the existence of relatively larger ice particle sizes. The median values of DFR at $12 \mathrm{~km}$ are higher over central North America, Argentina, central Africa, and northeast China, which is similar to the global distribution pattern of maximum height of $40 \mathrm{~dB} Z$ (Liu and Zipser 2015). The median DFR values in central Africa is generally larger than that in the Amazon. This implies that central African convective cores have stronger updrafts to lift larger ice particles to $12 \mathrm{~km}$ than those over Amazon (Petersen and Rutledge 2001; Williams and Sátori 2004; Zipser et al. 2006; Liu and Zipser 2015). This is also consistent with stronger convection over central Africa with more lightning flashes than those over Amazon (Christian et al. 2003). Also note that subtropical regions, such as central North America and Argentina, have higher DFR values than central Africa, which is consistent with the larger hail sizes with stronger ice scattering signal at $37-\mathrm{GHz}$ microwave radiance in the subtropics (Cecil and Blankenship 2012; Ni et al. 2017). Though only a few DCC cases are found north of the Mediterranean Sea, they have high DFR values. It is interesting to see high DFR values at $12 \mathrm{~km}$ over northeast China, which is close to the hot spot of convection overshooting the tropopause over the region (Liu and Liu 2018). To further test if DFR values would vary for the same radar reflectivity, the median DFR values at the maximum height of $20-\mathrm{dB} Z$ echo (MAXHT20Ku) are derived at the same grids and shown in Fig. 2c. Although both the DCC number and grid-mean DFR show significant regional variations in the tropics (Figs. 2a,b), the median DFR values at $20-\mathrm{dB} Z$ echo tops are smaller than $1.5 \mathrm{~dB}$. This suggests that at the heights of $20-\mathrm{dB} Z$ echo tops, there are not many large ice particles to lead to strong Mie scattering at Ka band. The regional variation of DFR at $20-\mathrm{dBZ}$ echo-top heights is not obvious, but still is slightly larger over the intense convection hot spot regions. This indicates that even with the same $20-\mathrm{dB} Z$ radar reflectivity, stronger convective cores are likely to have 

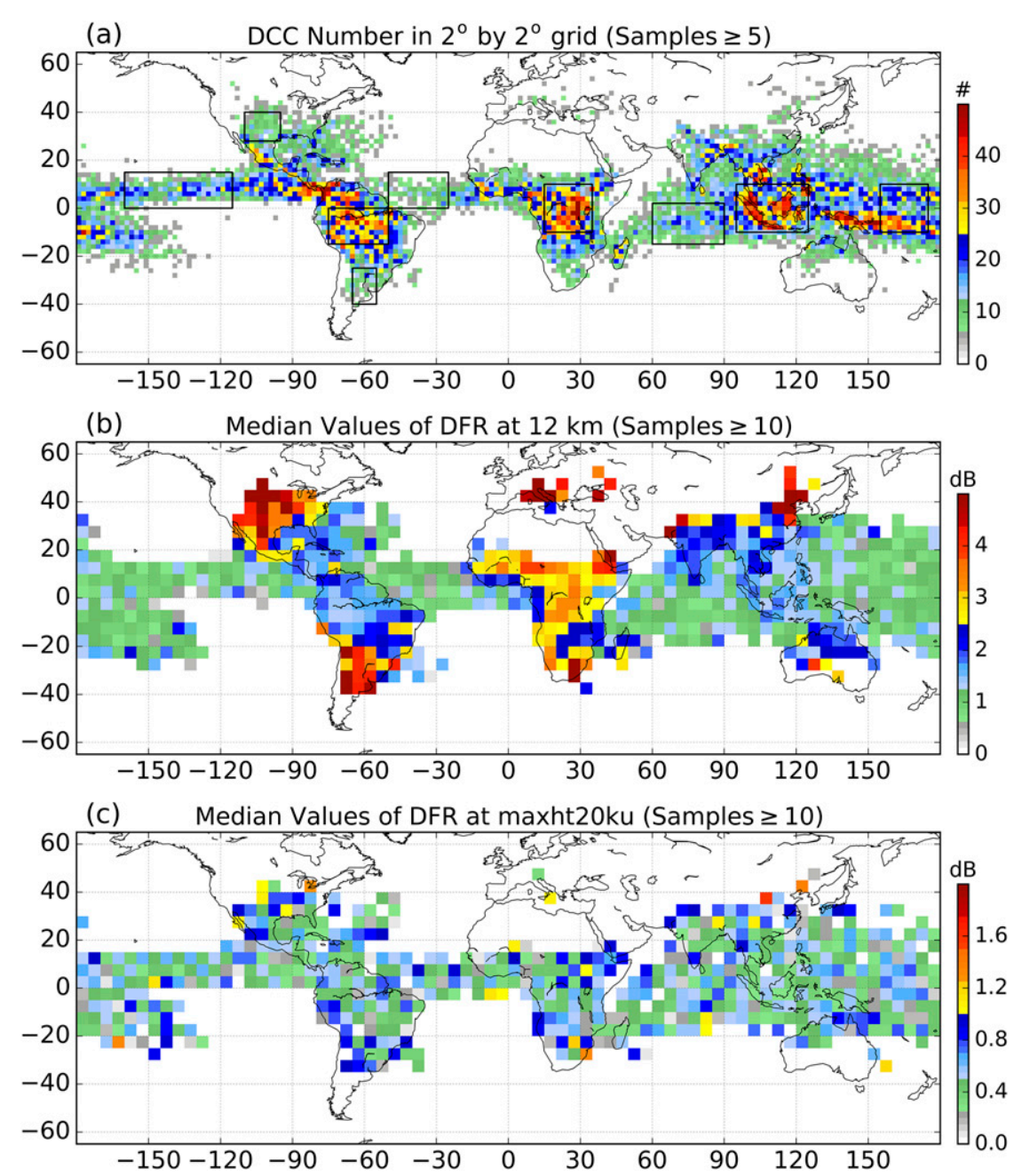

FIG. 2. (a) Global distributions of population of deep convection cores (DCCs) in $2^{\circ} \times 2^{\circ}$ grid boxes from GPM dual-frequency radar observations from March 2014 to February 2017; only grids with more than five samples are shown. (b) Grid median values of dual-frequency ratio at $12 \mathrm{~km}$ in each $5^{\circ} \times 5^{\circ}$ grid box. (c) Grid median values of dual-frequency at MAXHT20Ku in $2^{\circ} \times 2^{\circ}$ grid box. The regions of interest are boxed in (a).

larger ice particles, which is directly related to the updraft intensity.

The contoured frequency by altitude diagram (CFAD) of DCC reflectivity profiles and percentiles of reflectivity at different altitudes over tropics are shown in Fig. 3. The $\mathrm{Ku}$-band reflectivities have a wider range of distribution with higher values than Ka-band reflectivities over both ocean and land. Ka-band reflectivity values truncated around $33 \mathrm{dBZ}$ (Fig. 3b) over land due to the Mie scattering effect. As expected, both $\mathrm{Ku}-$ and Ka-band reflectivities over land are stronger than they are over ocean at both frequencies. Note that here the measured reflectivity values are shown; therefore, the attenuation effects are still included, especially at low-altitude levels. Measured Ka-band reflectivity rarely reaches $33 \mathrm{dBZ}$ over either land or ocean, likely due to mainly Mie scattering but perhaps in places also to attenuation.

CFADs of DFR profiles are shown in Figs. $3 \mathrm{c}$ and $3 \mathrm{f}$. Consistent with the differences between Figs. $2 b$ and 2e, the DFRs over land are larger than that of ocean. The median value profiles reach $15 \mathrm{~dB}$ at $2 \mathrm{~km}$ over land, but it reaches about $13 \mathrm{~dB}$ over ocean. The DFR begins to increase rapidly around $8 \mathrm{~km}$ over land and $5 \mathrm{~km}$ over ocean till where the $\mathrm{Ka}$ band gets close to $33 \mathrm{dBZ}$. The rapid increase of DFR is mainly caused by strong attenuation at Ka band as shown in Figs. $3 b$ and 3e, especially due to raindrops. Note that there is a considerable amount of negative DFR values over both land and ocean. Matrosov et al. (2005) found the DFR between 9.6 and $94 \mathrm{GHz}$ would be low as $-1.2 \mathrm{~dB}$ when the 

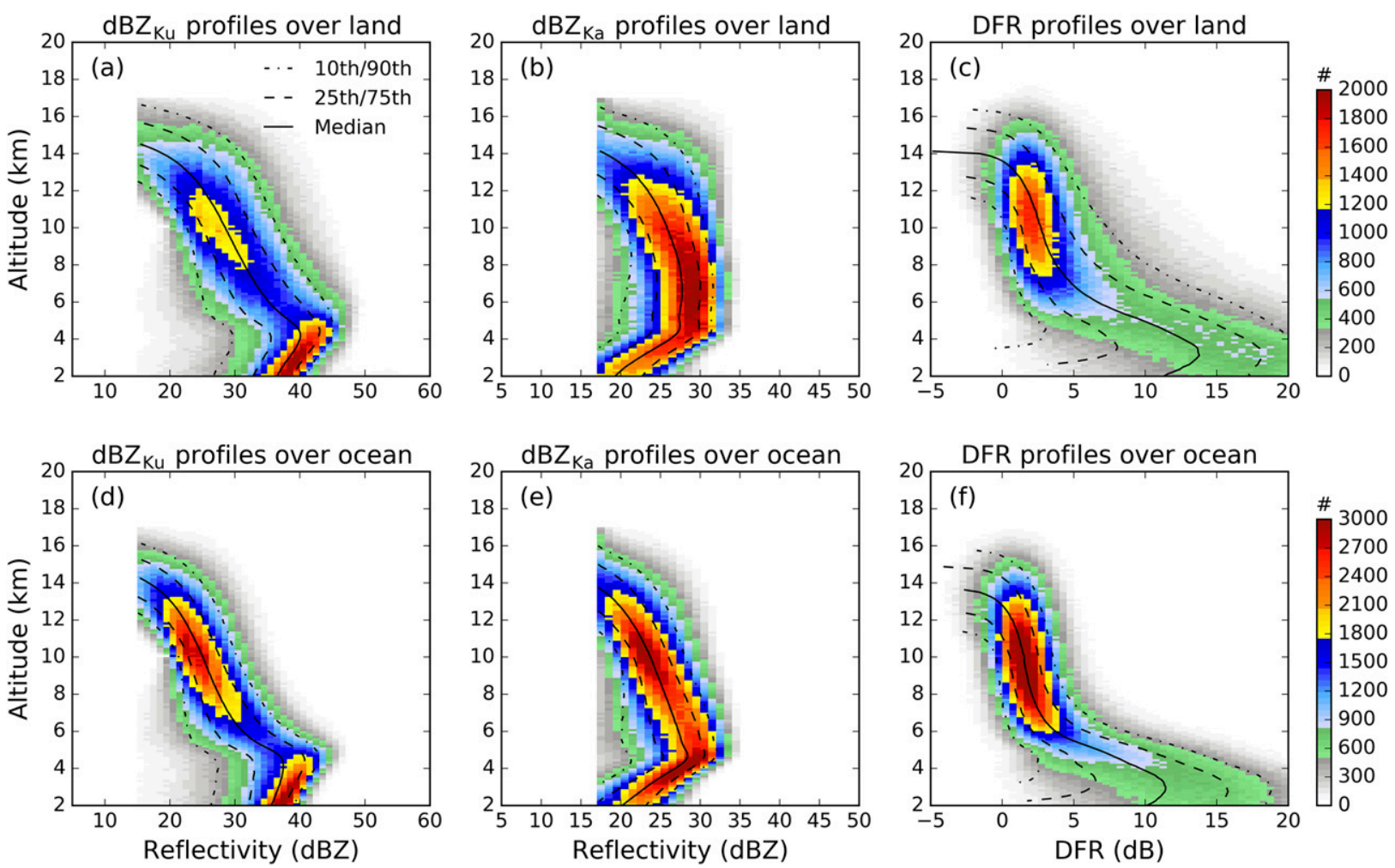

FIG. 3. Contoured frequency by altitude diagrams (CFADs) of (a),(d) Ku- and (b),(e) Ka-band radar reflectivities and (c),(f) dualfrequency ratios (DFRs) of DCCs over tropical $\left(20^{\circ} \mathrm{S}-20^{\circ} \mathrm{N}\right)$ (top) land and (bottom) ocean from April 2014 to March 2017. The 10th, 25th, 50th, 75th, and 90th percentiles are derived at each vertical level and overplotted.

median volume size of ice cloud particle is less than $0.5 \mathrm{~mm}$. In the calculation of Heymsfield et al. (2013), negative $\mathrm{Ku}-\mathrm{Ka}$ values occurred when ice particle diameter reaches around $10 \mathrm{~mm}$. In the discussion of Le and Chandrasekar (2014), the DFR of snow particles would be low as -0.1 to $-0.2 \mathrm{~dB}$ when median volume diameter less than $0.5 \mathrm{~mm}$. From these theoretical results, the negative DFR values might be caused by small snow particles less than $0.5 \mathrm{~mm}$ or ice particles above $10 \mathrm{~mm}$ because of differences in the normalizing factor. Because of the negative DFR, there are two possible solutions when DFR is used to retrieve microphysical parameters. To overcome this deficiency, Liao and Meneghini (2019) developed a modified model to amend the radar algorithm. The modification performed well in the retrieval of rain rates and particle size. Considering these complexities of hydrometeors and strong attenuation at low levels, we only focus on altitudes above $10 \mathrm{~km}$ and positive DFR values in discussions following.

In the GPM DPR convective versus stratiform precipitation classification (Le et al. 2009), slope of reflectivity with height and DFR are important indicators. Although only deep convection cores are investigated in this study, slope profiles are also examined in Fig. 4.
The slopes at $\mathrm{Ku}$ band are generally negative, which is consistent with the decrease of reflectivity with height shown in Fig. 3. Only a small fraction are positive. Over land, the 50th-percentile Ka-band reflectivity profile crosses the zero line near $8 \mathrm{~km}$ over land and near $4 \mathrm{~km}$ over ocean. This is likely due to stronger attenuation and Mie scattering in more intense convection over land. It is worth mentioning that in Figs. $4 \mathrm{~b}$ and $4 \mathrm{e}$, there are two slope peaks around the freezing level, indicating changes in concavity and convexity of the radar reflectivity profiles. The slope of DFR shows more complex variability, especially below the freezing level. Considering the attenuation and Mie scattering of $\mathrm{Ku}-$ and Ka-band radar reflectivity in areas with heavy precipitation rate and complex hydrometeors in the mixed phase region, we choose not to discuss these complicated variations at low levels in the present work.

\section{b. Properties of reflectivity profiles versus convective intensity}

As shown in Fig. 2b, the geographical distribution pattern of high DFR values at $12 \mathrm{~km}$ is close to where the most intense convection occurs (Zipser et al. 2006; Liu and Zipser 2015). Conventionally, the maximum height 

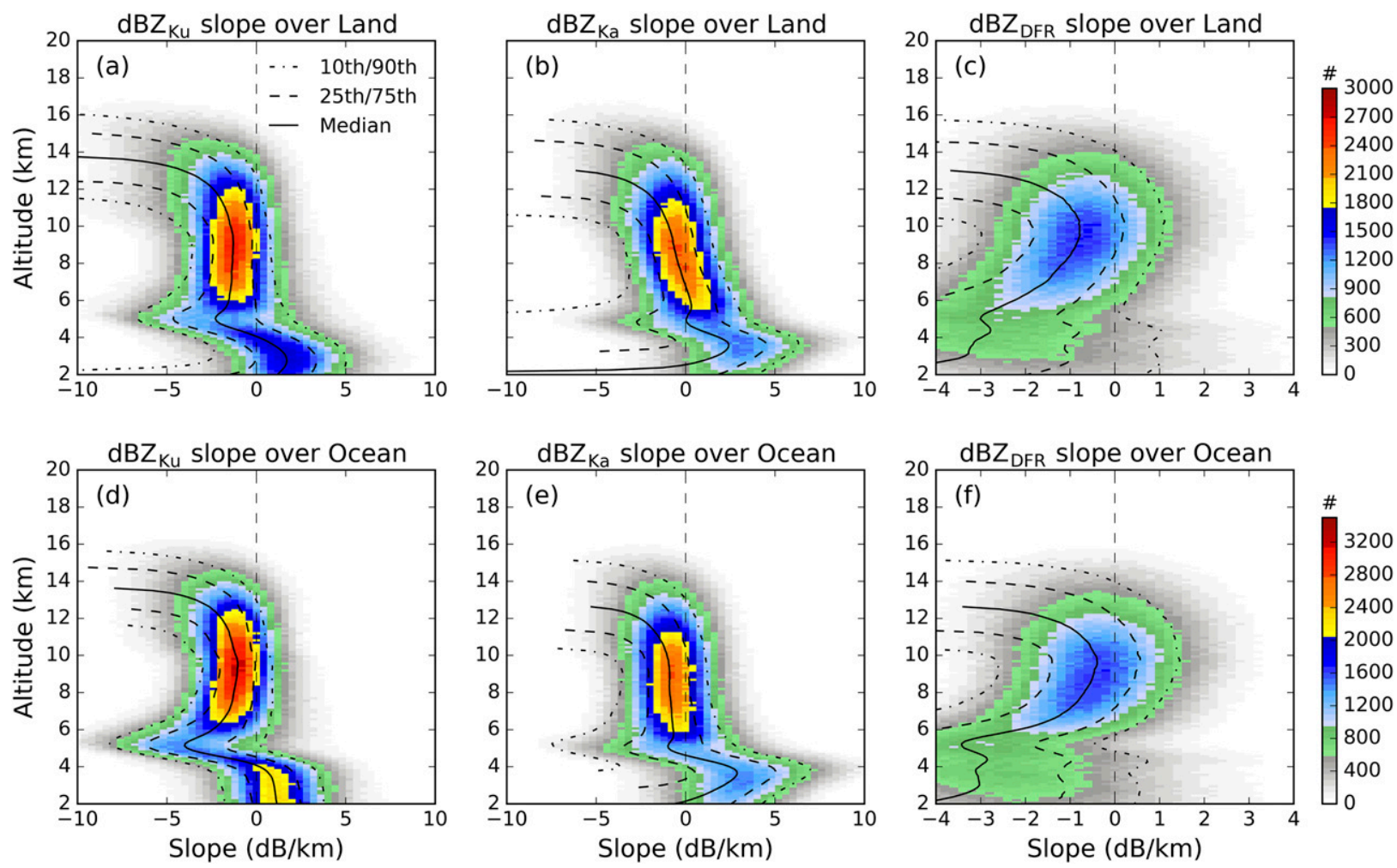

FIG. 4. As in Fig. 3, but for the vertical gradients, which are calculated by determining the difference of reflectivity or DFR between contiguous vertical levels and dividing by the vertical range resolution $(125 \mathrm{~m})$.

of 20 and $30 \mathrm{dBZ}$ can be used to imply the convective intensity. Generally, the stronger the updraft is, the higher the large ice particles are lifted, and at the higher altitudes, 20 and $30 \mathrm{~dB} Z$ would be observed, and the differences between 20- and 30-dBZ echo-top heights would be smaller. The relationships of DCC convective intensity and DFR at $12 \mathrm{~km}$ are shown in Fig. 5. About $64 \%$ of DCCs has the maximum $30-\mathrm{dB} Z$ echo-top height greater than $6.5 \mathrm{~km}$. The DFR is significantly correlated to convective intensity indicated by 20 - and $30-\mathrm{dB} Z$ echotop heights, especially over land (Figs. 5a,b). The DFR at $12 \mathrm{~km}$ increases with MAXHT20Ku and MAXHT30Ku in general. Over ocean, the relationship between DFR and the 20- and $30-\mathrm{dB} Z$ echo tops is not as obvious, but is also significant with $p$ value less than 0.05 . Due to the intensity of oceanic deep convection being typically weaker than continental storms, the DFR at $12 \mathrm{~km}$ over ocean rarely exceeds $4 \mathrm{~dB}$ at $12 \mathrm{~km}$. However, Figs. $5 \mathrm{~d}$ and 5 e still show a positive correlation between the 20- and 30-dBZ echo top and DFR over ocean. Regarding the 20- and 30-dBZ echo-top height differences (Figs. 5c,f), land DCCs have some values below $2 \mathrm{~km}$, decreasing with higher DFR values, corresponding to stronger convection. Over ocean, in contrast, the differences between 20- and $30-\mathrm{dBZ}$ echo-top heights are usually larger than $4 \mathrm{~km}$.
With different wavelengths at $\mathrm{Ku}$ and $\mathrm{Ka}$ bands, the electromagnetic waves interact with particles differently. The combination of the two channels would help in the retrieval of microphysical parameters. Typically, based on the radar equation, there are three likely influences on DFR profiles: 1) the Mie scattering effect, 2 ) the path-integrated attenuation, and 3) multiple scattering. Based on the Mie scattering theory, the radar reflectivity does not increase linearly (in log space) along with increasing particle sizes, when particle sizes are comparable to the radar wavelengths. The Ku band and $\mathrm{Ka}$ band perform differently in the Mie scattering regime. Battaglia et al. (2014) and Heymsfield et al. (2013) have discussed this effect for hydrometeors in gamma and monodisperse distributions. They both found a positive maximum DFR value when particle sizes are around $4 \mathrm{~mm}$, and complex fluctuations of DFR in the Mie scattering regime. According to their results, the Ka-band reflectivity departs from Rayleigh scattering starting when particle size reaches $1-2 \mathrm{~mm}$. Therefore, it would be quite common for ice particles to produce Mie scattering in convective cores.

The impact of attenuation on reflectivity and DFR profiles is distinct in Fig. 3, especially below the freezing level. Chandrasekar et al. (2003) discussed the relationship 

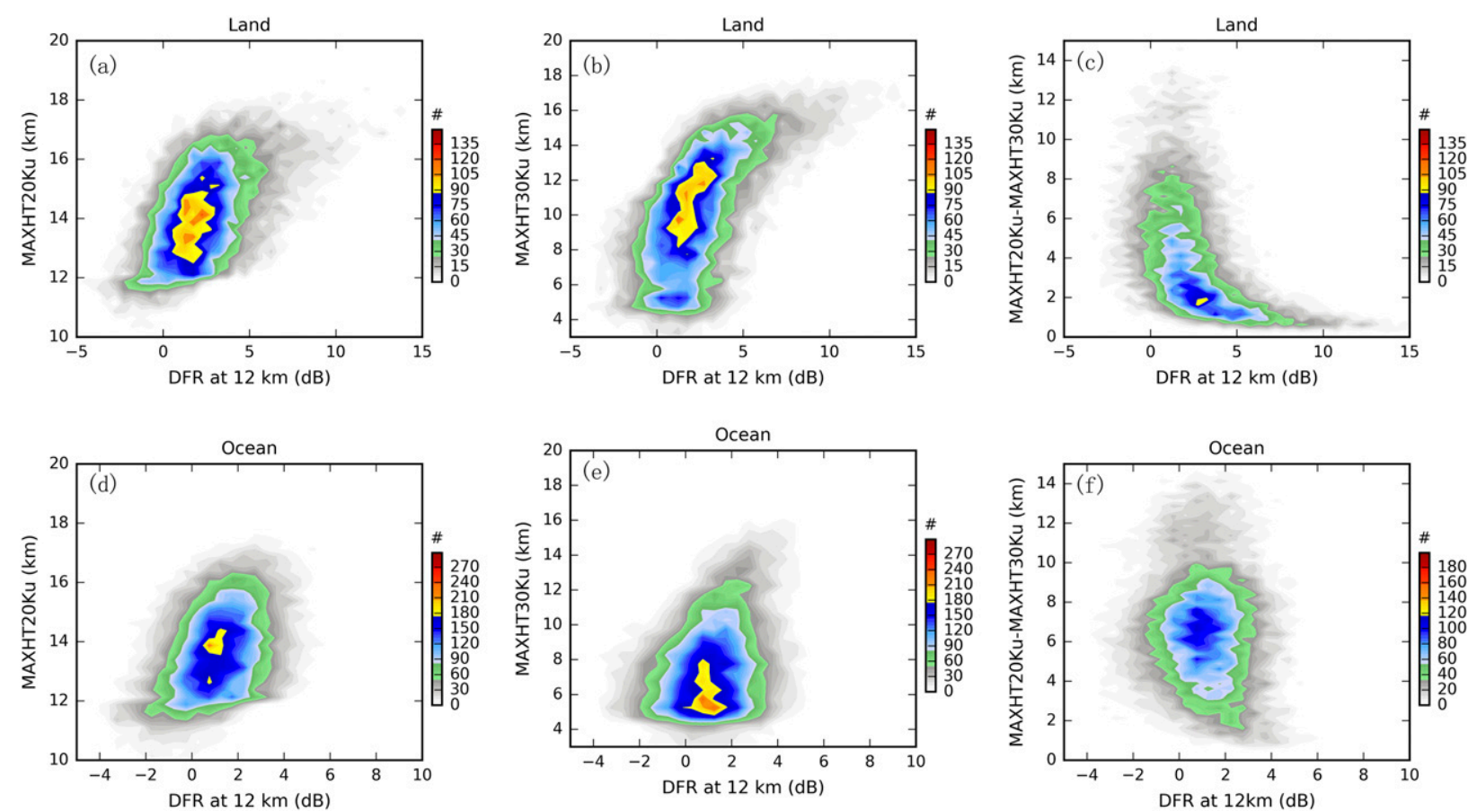

FIG. 5. Two-dimensional histograms of DCCs showing the relationship between DFR at $12 \mathrm{~km}$ and storm intensity indicated by (a),(d) MAXHT20, (b),(e) MAXHT30, and (c),(f) differences of MAXHT20 and MAXHT30 over tropical (20 $\left.{ }^{\circ} \mathrm{S}-20^{\circ} \mathrm{N}\right)($ top) land and (bottom) ocean.

of attenuation and reflectivity factor for rain, and showed that the specific attenuation is less than $0.5 \mathrm{~dB} \mathrm{~km}^{-1}$ when reflectivity is less than $40 \mathrm{dBZ}$. Above $10 \mathrm{~km}$ in DCC, reflectivity is mostly less than $40 \mathrm{dBZ}$ as shown in Fig. 2 . In addition, the attenuation correction algorithm of $\mathrm{Ku}$ and Ka reflectivity values in the ice regime in the current version 5 product is still under refinement. Therefore, we have chosen to examine the measured reflectivity instead. Significantly, in the region above $10 \mathrm{~km}$, the attenuation caused by ice particles is relatively less, especially over ocean (Fig. 2). Further discussion about attenuation is presented in section $4 \mathrm{c}$.

Recently, Battaglia et al. $(2015,2016)$ have investigated the impacts of multiple scattering (MS) effect on reflectivity and DFR profiles. One general feature of MS is that reflectivity profiles would be stretched below the level with strong attenuation because the scattered radiation is transferred back to the radar antenna after being multiply scattered. The MS is generally more apparent at $\mathrm{Ka}$ band than at $\mathrm{Ku}$ band and hence it could alter DFR profiles. However, in the CFAD of Ku-band and Ka-band reflectivity in Fig. 3 and the case shown in Fig. 1, the reflectivity profiles are not apparently stretched toward small values, and the "knee" (Battaglia et al. 2014) in the DFR plot is also not found. The majority of DCC profiles do not have sufficiently strong reflectivity to cause strong attenuation above $10 \mathrm{~km}$ (Fig. 3). Overall, the MS effect might occur in particularly intense convection at low levels, but its influences should be much smaller at the high-altitude levels we discuss here.

\section{Ice microphysical properties}

\section{a. A simple model to derive ice particle size distribution}

To further interpret the DFR values, we attempt to derive the microphysical properties of ice particles in DCCs using $\mathrm{Ku}$ and $\mathrm{Ka}$ reflectivities. Using the simulation method introduced in section $2 \mathrm{~b}$, a simple method of retrieval is schematically shown in Fig. 6. With the assumption of spherical shape with modified gamma particle size distribution, and mass-diameter relationship, the unattenuated $\mathrm{Ku}$ and Ka reflectivity are simulated according to various PSDs with consideration of Mie scattering using the QuickBeam package. Then, with simulated reflectivity and PSD parameters, lookup tables are constructed as shown in Fig. 7. Note that in ranges with DFR larger than $15 \mathrm{~dB}$, the relationships between radar reflectivities and microphysical parameters become nonmonotonic and complex, but the DFR rarely exceeds $15 \mathrm{~dB}$ as shown in Fig. 3. Therefore, we only show the relationship with DFR values less than $15 \mathrm{~dB}$. We also ignore any negative DFR values. As a result, parameters of PSD size distribution, including 


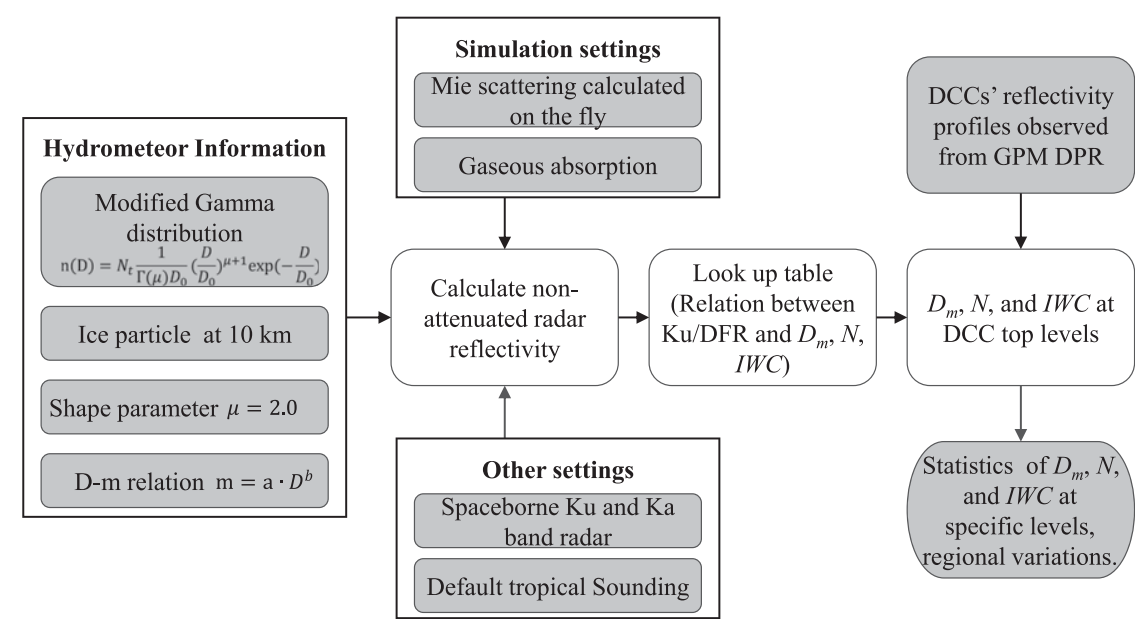

FIG. 6. Schematic diagram of the procedure for the retrieval process of microphysical parameters using radar simulation package QuickBeam.

mean diameter $D_{m}$, total ice particle concentration $N$, and IWC can be derived from Ku reflectivity and DFR in a one to one relationship by using the lookup tables in Fig. 7. With the assumption of modified gamma PSD, $D_{m}$ is only a function of DFR (Fig. 7a). Kuo et al. (2016) also discussed the relationship between DFR and ice particle size and found that when liquid equivalent median volume diameter $D_{m}$ is $1 \mathrm{~mm}$, then DFR is around $5 \mathrm{~dB}$, depending on the density functions. The result of $D_{m}$ in Fig. 7a is consistent with Kuo et al. (2016) that 5-dB DFR corresponds to $D_{m}$ of slightly larger than $1 \mathrm{~mm}$. As shown as in Figs. $7 \mathrm{~b}$ and $7 \mathrm{c}, N$ and IWC are also functions of both $\mathrm{Ku}$ reflectivity and DFR.

\section{b. Regional variation of ice particle size distribution near the top of convective cores}

Once the lookup tables are constructed, they are applied to reflectivity and DFR profiles from DCCs at altitudes above $10 \mathrm{~km}$. The geographical distribution of median microphysical parameters at $12 \mathrm{~km}$ is shown in Fig. 8. Consistent with high DFR values in Fig. 3b, values of $D_{m}$ over land are typically larger than those over ocean (Fig. 8a). G. M. Heymsfield et al. (2010) examined vertical updrafts of different types of tropical deep convection using airborne observations. Results showed that the maximum updrafts of continental convection are stronger than oceanic convection above $10 \mathrm{~km}$. Figure 8 shows larger particle sizes over land, which is consistent with stronger updrafts in continental convection. In the tropics, the equatorial Africa regions have the largest mean diameter. However, the DCCs in several subtropical regions, such as central North America and Argentina, tend to have even larger $D_{m}$ than central Africa. The regional distribution of median $D_{m}$ are consistent with convection intensity indicated by the precipitation radar on TRMM (Zipser et al. 2006). For the same low polarization-corrected temperature (PCT) at 37-GHz channel, Ni et al. (2017) have found
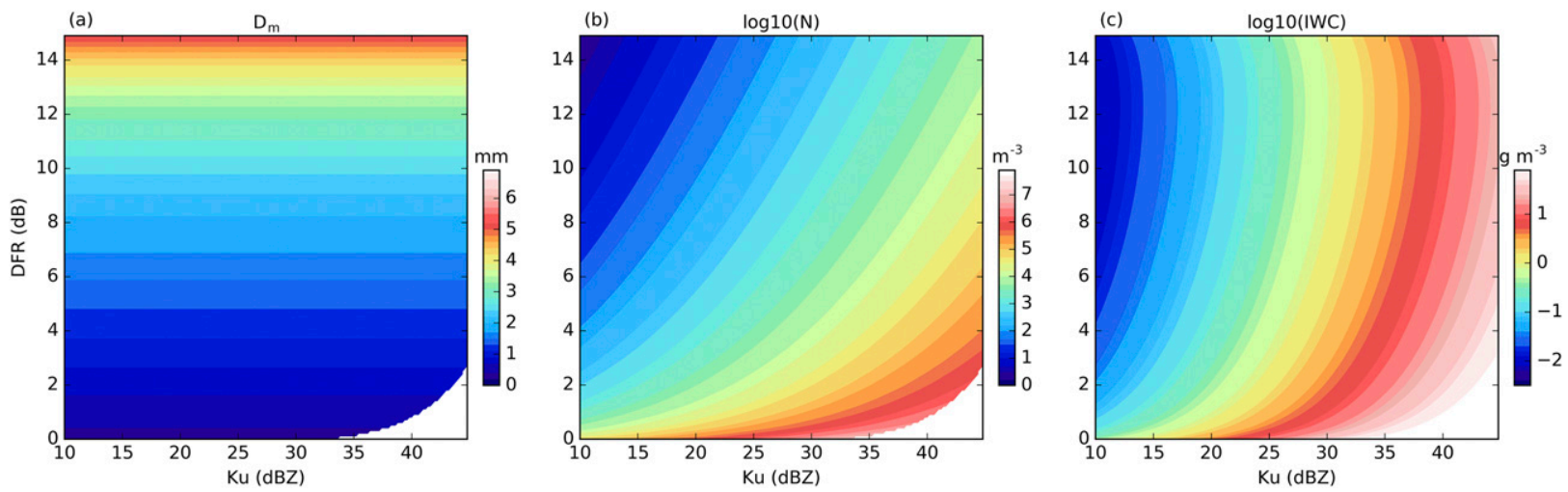

FIG. 7. Lookup tables for calculating (a) mean diameter $D_{m}$, (b) total ice particle number $N$, and (c) ice water content (IWC) based on $\mathrm{Ku}$ reflectivity and $\mathrm{Ku}$ - and $\mathrm{Ka}$-band dual-frequency ratio. 

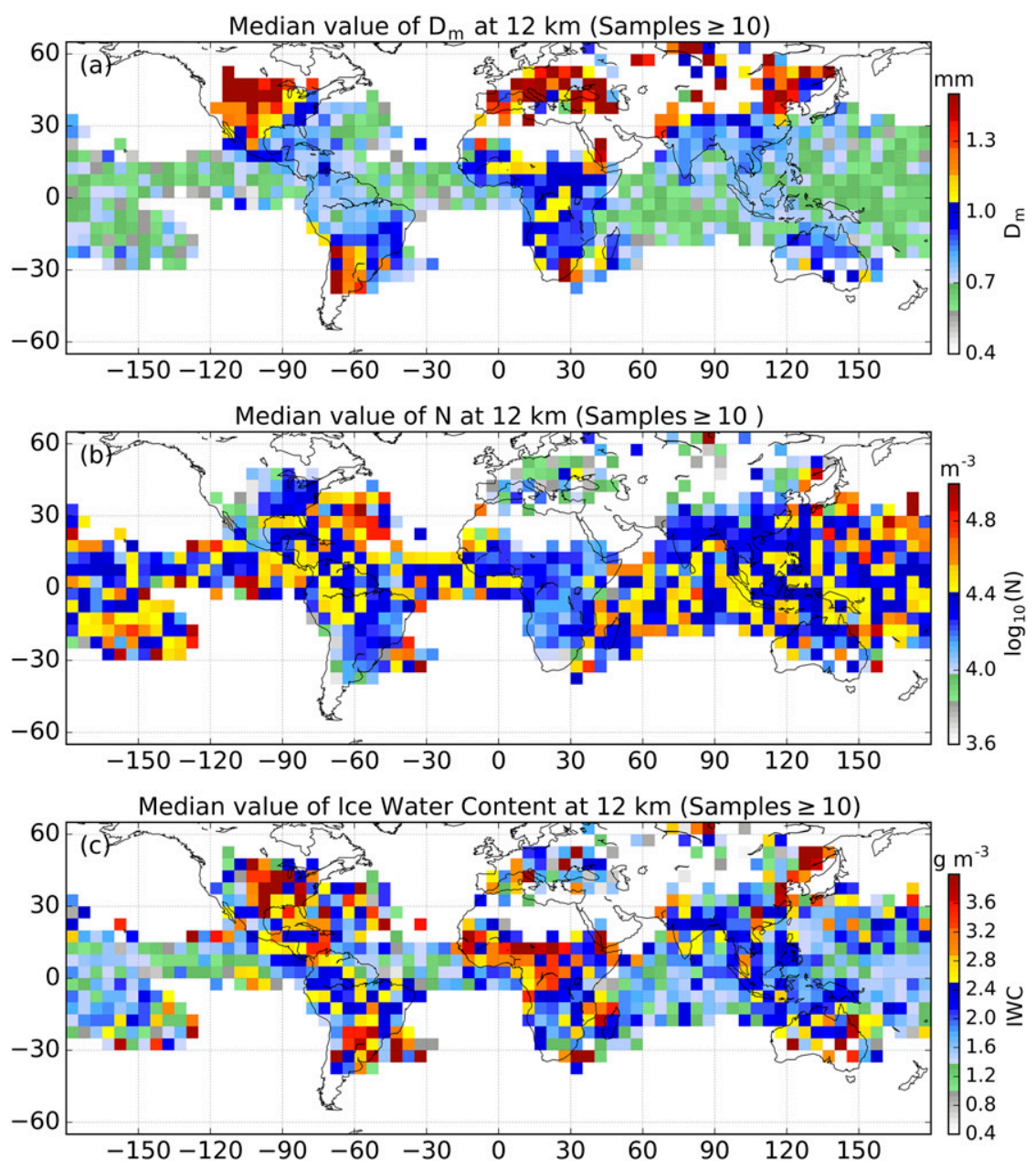

FIG. 8. Global distributions of median values of microphysical parameters at $12 \mathrm{~km}$ : (a) mean diameter $D_{m}$, (b) ice particle number $N$, and (c) ice water content (IWC). The median values are computed in $5^{\circ} \times 5^{\circ}$ grids with at least 10 samples. The median values are calculated without including zero values.

that tropical convection tends to have higher radar echo top but weaker reflectivity at altitudes than subtropical intense convection. This can be interpreted by the larger diameter of ice particles in subtropical convection indicated in Fig. 8a because it is known that a low $37-\mathrm{GHz}$ PCT is related to large ice particles (Cecil 2009). The number concentration $N$ in Fig. 8 b show almost opposite from $D_{m}$ with higher number concentration of ice particles at $12 \mathrm{~km}$ over ocean than land in general. Equatorial Africa has the lowest $N$ in the tropics. In Fig. $8 \mathrm{c}$, there is higher IWC at $12 \mathrm{~km}$ in DCCs over land than over ocean. At $12 \mathrm{~km}$, land convection tends to have higher reflectivity than over ocean due to stronger updrafts, which is also consistent with higher IWC. This is consistent with some earlier studies (e.g., Carey and Rutledge 2000; Petersen and Rutledge 2001; Cecil 2009). However, because of the assumptions in the lookup tables, the results of $N$ and IWC are not as robust as $D_{m}$, and still need further validation in the future.

In addition to the microphysical parameters at specific heights, it is interesting to examine the variability of microphysical parameters for the same radar reflectivity. Figures 9 and 10 show the geographical distribution of microphysical parameters at the $20-\mathrm{dB} Z$ height from $\mathrm{Ku}$ and Ka radars, respectively. Note that Figs. 9 and 10 only focus on near the very top of convection that varies regionally. For example, MAXHT20Ka over ocean is in general lower than that over land. Because there is relatively low reflectivity above the $20-\mathrm{dB} Z$ height, the attenuation would typically be low. In the current version 5 product, about $43 \%$ of the DCC profiles have Ku-band reflectivity less than $20 \mathrm{~dB} Z$ at the $20-\mathrm{dB} Z \mathrm{Ka}$-band echotop heights, which results in negative DFR and hence they are ignored in the retrieval. Figures 9 and 10 only 

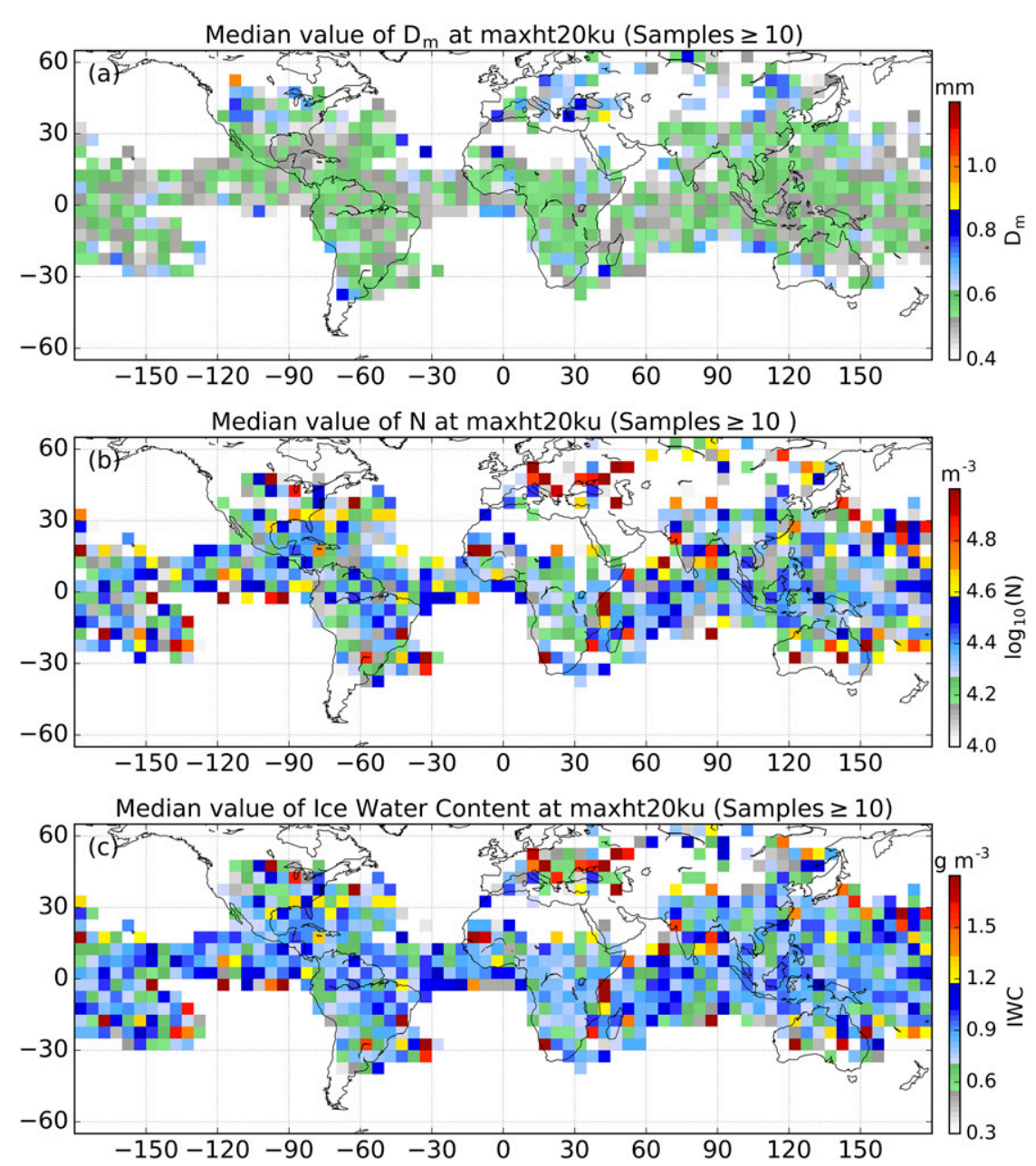

FIG. 9. As in Fig. 8, but for microphysical parameters at MAXHT20Ku.

showed the results of valid data when DPR does detect a strong Mie effect. In Fig. 9, the derived $D_{m}$ over midlatitudes is slightly larger than that in tropics. As shown in Table 1, the $N$ and IWC at MAXHT20Ku are very close in all nine regions. Unlike the results at MAXHT20Ku, parameters at MAXHT20Ka show more obvious regional discrepancies. Generally, land (midlatitude) grids have larger $D_{m}$, less IWC, and less $N$ than ocean (tropics) at MAXHT20Ka. Larger $D_{m}$ over land from retrieval means larger DFR and smaller Ka-band reflectivity at this level mainly due to Mie scattering. The median values of $D_{m}$ were around $0.5 \mathrm{~mm}$ over tropical oceans and $0.9 \mathrm{~mm}$ over subtropical land (Table 1 ). In the tropics, central Africa has larger particle sizes than Amazon and Maritime Continent, but smaller number concentrations. Meanwhile, the median values of IWC at MAXHT20Ka range from 0.63 to $1.10 \mathrm{~g} \mathrm{~m}^{-3}$. These results suggest that even with the same reflectivity near the top of convection, continental convection has relatively larger DFR and ice particles than those over ocean.
The parameters, especially IWC, at $12 \mathrm{~km}$ show geographical distributions different from that at $20-\mathrm{dB} Z$ echo-top heights. The main reason is the regional difference in vertical convective structures of DCCs ( $\mathrm{Ni}$ et al. 2017). The continental DCC profiles have higher reflectivity at $12 \mathrm{~km}$ and higher $20-\mathrm{dB} Z$ echo-top heights than over ocean (Zipser et al. 2006). To further understand the vertical distribution of microphysical parameters, the CFAD of microphysical parameters above $10 \mathrm{~km}$ are shown separately over land and ocean in Fig. 11. The CFADs of $D_{m}$ indicates a larger ice particle size in convective cores over land (Fig. 11a) than over ocean (Fig. 11d). The $D_{m}$ values exceed $2 \mathrm{~mm}$ at $10 \mathrm{~km}$ and decrease with height in DCCs over land. Over ocean, the $D_{m}$ values have a narrower value range and are less than $1.5 \mathrm{~mm}$ at levels above $10 \mathrm{~km}$. The number concentrations of ice particles in DCCs are in general larger over ocean than over land at all altitudes. Based on the calculation, it is common that IWC have values above $2 \mathrm{~g} \mathrm{~m}^{-3}$ in the DCCs around $10 \mathrm{~km}$ over both land 

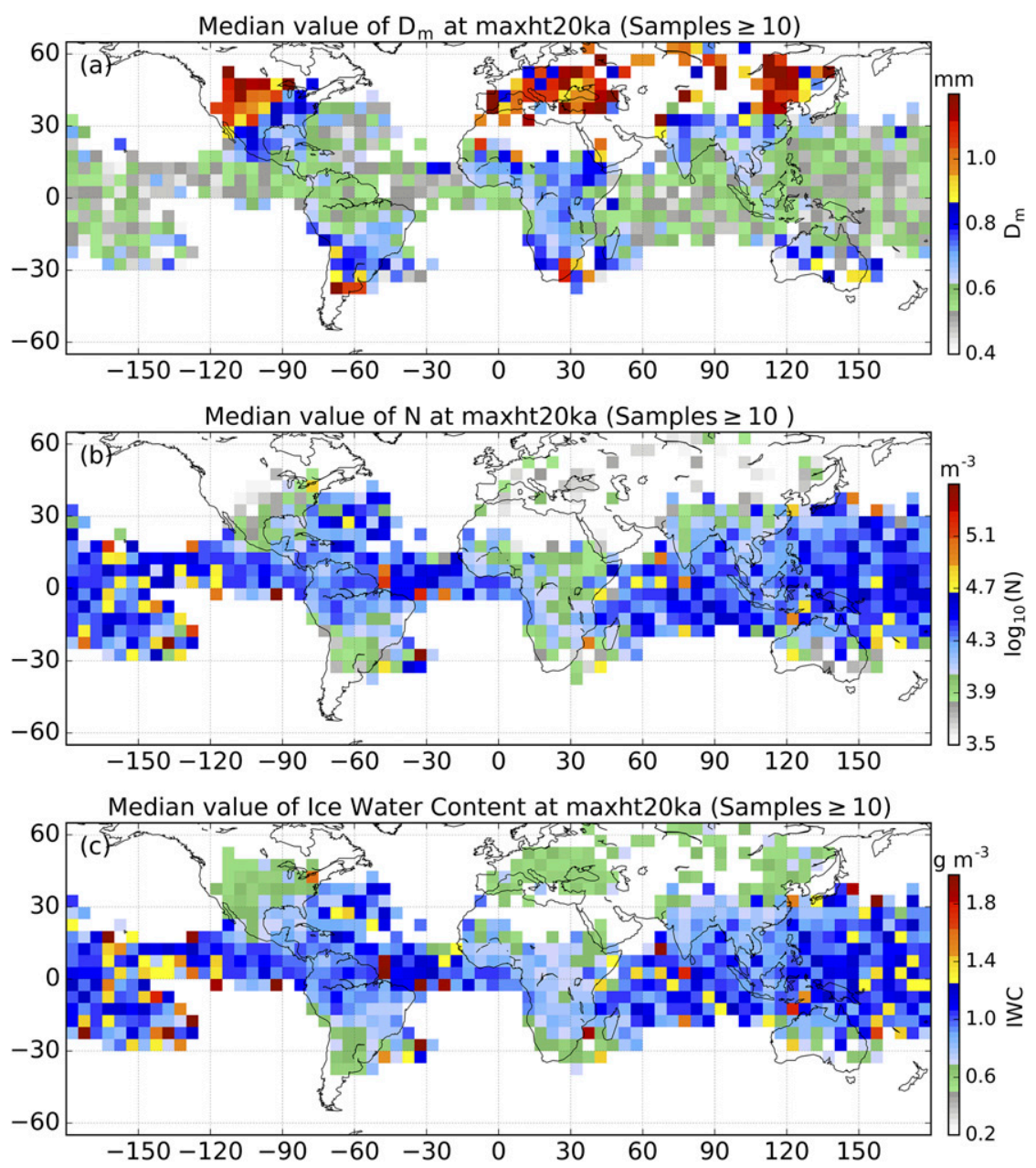

FIG. 10. As in Fig. 8, but for microphysical parameter at MAXHT20Ka.

and ocean, with higher values in the land DCCs. The median lines in Figs. 11a-f are overlaid in Figs. 11h-j to emphasize on the land versus ocean differences. Overall, at all heights above $10 \mathrm{~km}$, continental DCCs have larger $D_{m}$, less $N$, and higher IWC than oceanic DCCs, except that the two profiles of number concentration cross around $11 \mathrm{~km}$.

As a reference, the median values of $D_{m}$ and $N$ from GPM 2A.DPR products are also presented in Figs. $11 \mathrm{~h}-\mathrm{j}$. The results of 2A.DPR products showed larger particle size and lower concentration than the results of the simple retrieval. As this study used measured reflectivity, the attenuation correction might be one important reason that caused the diameter differences between the two methods. Nevertheless, the contrast between ocean and land is similar, so that comparisons of parameters in different regions are robust. Using in situ observations in the TRMM field campaign, Heymsfield et al. (2002) showed the IWC around $0.2 \mathrm{~g} \mathrm{~m}^{-3}$, accompanied with $10-\mathrm{dBZ}$ reflectivity, in stratiform regions and anvil, which is significantly smaller than that in the DCC at $12 \mathrm{~km}$. Wang et al. (2005) developed a relationship to retrieve ice cloud microphysical properties using data from the ER-2 aircraft. In the cases from CRYSTAL-FACE, IWC was found to reach $1.5 \mathrm{~g} \mathrm{~m}^{-3}$ above $10 \mathrm{~km}$, while the generalized effective sizes were typically less than $1 \mathrm{~mm}$.

Though in general, there are significant differences in microphysical properties of ice particles in DCCs over land and ocean, there are also large regional variations in different land regions. For example, it is clear that Amazon and Maritime Continent have properties closer to oceanic (Figs. 8, 9, and 10). To demonstrate the regional variations, we summarize the median values of reflectivities, DFR, and ice microphysical properties over nine selected areas as boxes in Fig. 2a. The median vertical profiles are shown in Fig. 12 and the values at $12 \mathrm{~km}$, and 20-dBZ echo-top heights are listed in Table 1. Four oceanic regions (western Pacific, Indian Ocean, Atlantic, and eastern Pacific; solid curves in Fig. 12) have much smaller regional variations than 
TABLE 1. Population of deep convective cores (DCCs) over selected regions (boxes in Fig. 2a), and the median values of DFR derived with dual-frequency reflectivity and derived microphysical parameters using lookup tables. Zero values are excluded in the calculation.

\begin{tabular}{|c|c|c|c|c|c|c|c|c|c|}
\hline & \multicolumn{2}{|c|}{ Subtropical } & \multicolumn{7}{|c|}{ Tropical } \\
\hline & \multirow[b]{2}{*}{$\begin{array}{c}\text { Southeast } \\
\text { United States }\end{array}$} & \multirow[b]{2}{*}{ Argentina } & \multicolumn{3}{|c|}{ Land } & \multicolumn{4}{|c|}{ Ocean } \\
\hline & & & $\begin{array}{c}\text { Central } \\
\text { Africa }\end{array}$ & Amazon & $\begin{array}{l}\text { Maritime } \\
\text { Continent }\end{array}$ & $\begin{array}{c}\text { West } \\
\text { Pacific }\end{array}$ & $\begin{array}{l}\text { India } \\
\text { Ocean }\end{array}$ & Atlantic & $\begin{array}{c}\text { East } \\
\text { Pacific }\end{array}$ \\
\hline DCC number (unitless) & 430 & 282 & 2802 & 2587 & 1842 & 2121 & 1509 & 647 & 1725 \\
\hline MAXHT30Ku $(\mathrm{km})$ & 11.05 & 10.91 & 10.98 & 8.44 & 8.78 & 6.76 & 6.41 & 6.11 & 6.08 \\
\hline MAXHT30Ka (km) & 8.15 & 9.13 & 7.87 & 5.68 & 5.93 & 5.06 & 4.86 & 4.86 & 4.98 \\
\hline MAXHT20Ku (km) & 12.80 & 12.99 & 14.21 & 13.93 & 13.82 & 13.43 & 13.09 & 12.89 & 12.96 \\
\hline MAXHT20Ka (km) & 12.60 & 12.79 & 14.04 & 13.85 & 13.75 & 13.45 & 13.13 & 12.84 & 13.02 \\
\hline DFR_12 km (dB) & 4.00 & 4.04 & 3.05 & 1.64 & 1.78 & 1.03 & 0.96 & 0.93 & 0.97 \\
\hline D_12 $\mathrm{km}(\mathrm{mm})$ & 1.20 & 1.20 & 1.02 & 0.78 & 0.80 & 0.66 & 0.65 & 0.66 & 0.65 \\
\hline IWC_12 km $\left(\mathrm{g} \mathrm{m}^{-3}\right)$ & 2.89 & 2.87 & 2.69 & 2.38 & 2.40 & 1.53 & 1.51 & 1.28 & 1.26 \\
\hline $\mathrm{N} \_12 \mathrm{~km}\left(\mathrm{~m}^{-3}\right)$ & 12364 & 14581 & 15329 & 25220 & 24631 & 25287 & 25752 & 21106 & 21017 \\
\hline DFR_MAXHT20Ku (dB) & 0.66 & 0.72 & 0.53 & 0.49 & 0.41 & 0.53 & 0.51 & 0.49 & 0.47 \\
\hline DFR_MAXHT20Ka (dB) & 1.96 & 1.75 & 0.96 & 0.27 & 0.25 & -0.16 & -0.11 & -0.07 & -0.14 \\
\hline D_MAXHT20Ku (mm) & 0.56 & 0.54 & 0.56 & 0.55 & 0.54 & 0.54 & 0.55 & 0.52 & 0.53 \\
\hline D_MAXHT20Ka (mm) & 0.91 & 0.85 & 0.69 & 0.59 & 0.60 & 0.51 & 0.54 & 0.52 & 0.52 \\
\hline IWC_MAXHT20Ku $\left(\mathrm{g} \mathrm{m}^{-3}\right)$ & 0.79 & 0.85 & 0.78 & 0.80 & 0.85 & 0.83 & 0.82 & 0.90 & 0.87 \\
\hline IWC_MAXHT20Ka $\left(\mathrm{g} \mathrm{m}^{-3}\right)$ & 0.63 & 0.63 & 0.75 & 0.92 & 0.90 & 1.15 & 1.04 & 1.10 & 1.11 \\
\hline N_MAXHT20Ku $\left(\mathrm{m}^{-3}\right)$ & 18117 & 21207 & 17677 & 18941 & 21382 & 20259 & 19526 & 23913 & 22558 \\
\hline N_MAXHT20Ka $\left(\mathrm{m}^{-3}\right)$ & 4848 & 5941 & 10720 & 18702 & 17711 & 32601 & 26138 & 29342 & 30392 \\
\hline
\end{tabular}

five continental regions (central Africa, United States, Amazon, Argentina, and Maritime Continent; dashed curves in Fig. 12) in all parameters. Over oceanic regions, the Ku-band and Ka-band reflectivity profiles are very close and lead to around $1 \mathrm{~dB}$ in DFR at $12 \mathrm{~km}$. The measurement accuracy of the dual-frequency radar is $\pm 1 \mathrm{dBZ}$ (Hou et al. 2014), which makes the accuracy one important consideration in understanding microphysical parameters derived from small DFR values. Also $D_{m}$, IWC, and $N$ over oceanic regions have smaller regional variations than those over land. The five continental regions could be divided into two subgroups: tropics and subtropics. Generally, both of the two subgroups have stronger reflectivity, larger $D_{m}$, and higher IWC than oceanic regions. Among tropical continental regions, the Amazon and Maritime Continent have weaker reflectivity than central Africa at both $\mathrm{Ku}$ and Ka bands, resulting in smaller DFR and $D_{m}$. The median line of $D_{m}$ in the Amazon and Maritime Continent are between those of oceanic regions and of central Africa in Figs. 12e and 12f. Central Africa has the largest ice particle size and highest IWC in the tropics, indicating that strong convection could lift larger ice particles to higher altitudes. In the subtropics, there are relatively fewer DCC samples over the United States and Argentina than tropical regions (Table 1), mainly because the convection over the United States and Argentina, although often intense, usually has somewhat lower echo tops than those over tropics due to a lower tropopause height.
However, they have higher reflectivity at Ku band than those in the tropics at altitudes above $8 \mathrm{~km}$. At Ka band, Argentina has the highest reflectivity between 6 and $10 \mathrm{~km}$ among all regions.

\section{c. Uncertainties in the ice particle distribution estimates}

Although the results of land versus ocean contrast are consistent with many past studies showing more intense convection over continents, there are still some caveats in the uncertainty of derived values of ice microphysical properties. First, there are no in situ observations to justify our assumption of the modified gamma size distribution for ice particles and it is of course likely that the assumption of spherical shape of ice particles is incorrect. Based on the analysis of Kuo et al.(2016), after considering more complicated ice particle shapes, $D_{m}$ and IWC could be larger than what we have derived. The mass-dimension relation used in this study is from a few convective cases during the NAMMA field campaign (A. J. Heymsfield et al. 2010). However, it is reasonable to question if the same mass-dimension relation can be applied to convective cores over different regions globally.

We have neglected the attenuation in the derivation of ice microphysical properties using the lookup tables. The measured reflectivity without attenuation correction have been used to derive the microphysical parameters. However, with estimated ice particle distribution, we 

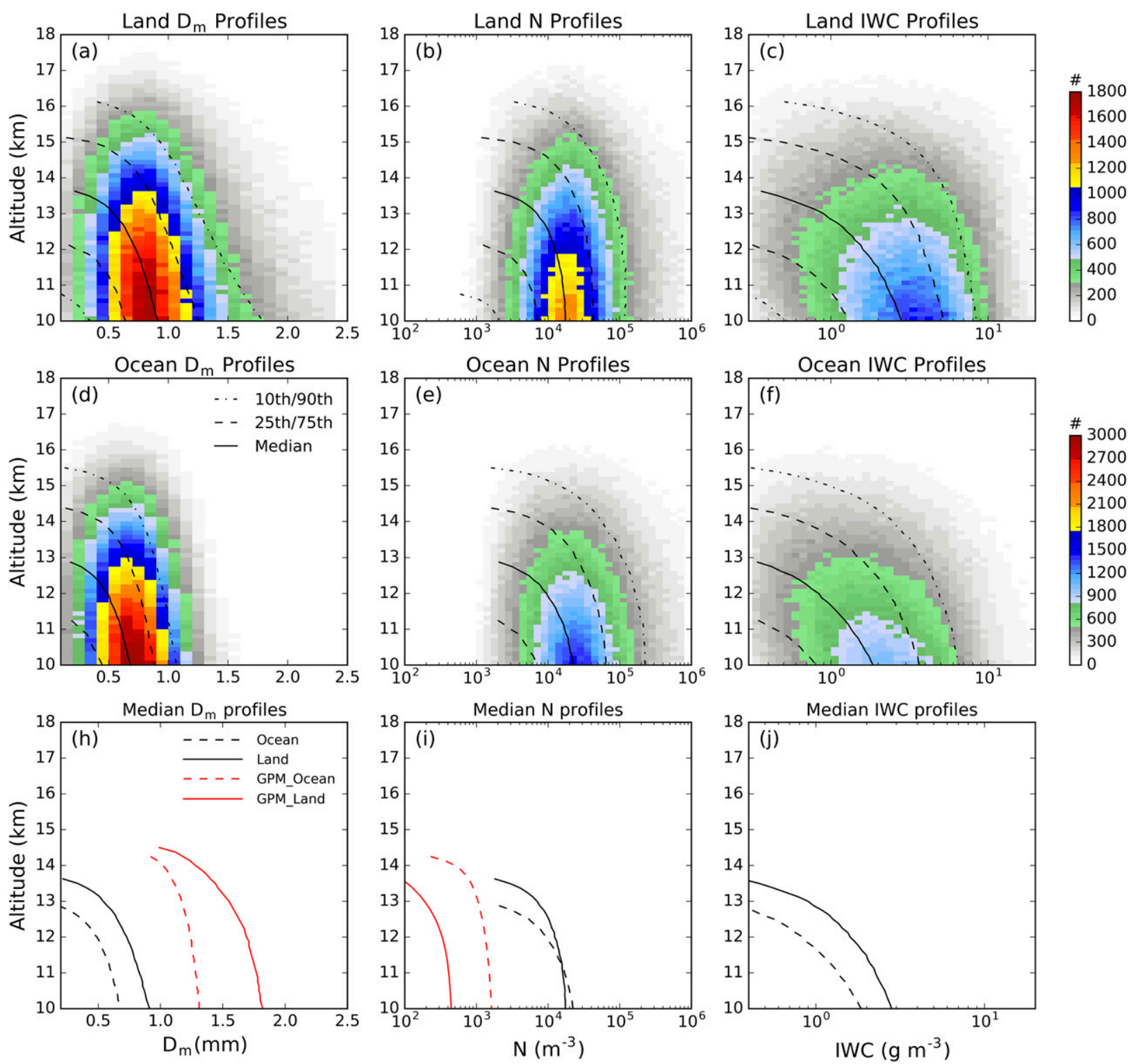

FIG. 11. Contoured frequency by altitude diagrams (CFADs) of microphysical parameters: (a),(d) mean diameter $D_{m}$, (b),(e) total ice particle number $N$, and (c),(f) ice water content (IWC) over tropical (a)-(c) land and (d)-(f) ocean. The percentiles of microphysical parameters are calculated at each level. (h)-(j) The median profiles in (a)-(f). The $D_{m}$ and $N$ results of GPM DPR retrieval products are also plotted.

can estimate the attenuation after feeding this distribution to the QuickBeam. Only microphysical parameters between 10 and $16 \mathrm{~km}$ are used and results are shown in Fig. 13. Although the attenuation at each $125-\mathrm{m}$ altitude bin is as small as $0.02 \mathrm{~dB}$, the median value of pathintegrated DFR from 16 to $10 \mathrm{~km}$ is near $0.7 \mathrm{~dB}$ over land (Fig. 13c), which is still considerable in the retrieval process. A relatively low attenuation near the top of convective cores is expected when reflectivity values are low, especially in oceanic convection (Fig. 13d). A significant amount of attenuation could exist in the strongest continental convection (Fig. 13a), where 30-40-dBZ echoes are observed reaching above $10 \mathrm{~km}$. For example, in hailstorms, the reflectivity around $-22^{\circ} \mathrm{C}$ (approximately $9 \mathrm{~km}$ in tropics) can reach $44 \mathrm{dBZ}$ (Ni et al. 2017), which raises more questions about the assumption. Although such intense convection do not account for high percentage of storms, further examination of microphysical properties of intense convection is needed.

Another uncertainty is the measurement accuracy of Ku-band and Ka-band reflectivity. At present, the 

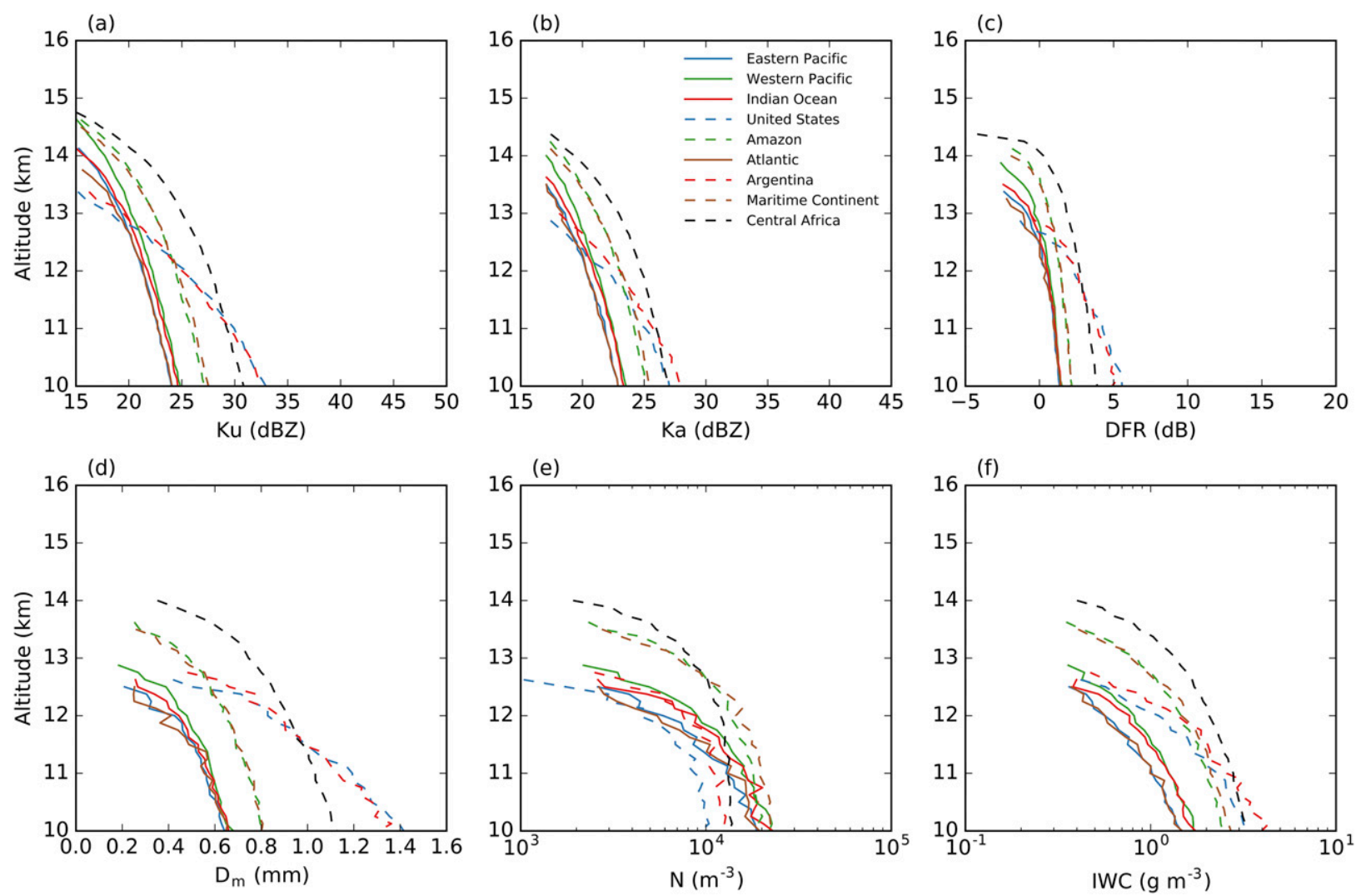

FIG. 12. Median values of DCC profiles of (a) Ku-band reflectivity, (b) Ka-band reflectivity, (c) dual-frequency ratio (DFR), (d) mean diameter, (e) total ice particle number, and (f) ice water content in four oceanic regions (solid lines) and five continental regions (dashed lines).

measurement accuracy of the dual-frequency radar reflectivity is $\pm 1 \mathrm{~dB}$. This can partially explain why $43 \%$ of $\mathrm{Ku}$ reflectivity is lower than $\mathrm{Ka}$ at the $20-\mathrm{dBZ}$ echo tops. In the retrieval process, a 1-dB bias in DFR could result in more than a $1-\mathrm{mm}$ bias in mean diameter.

Nevertheless, all the above uncertainties are difficult to quantify at present. Because there are insufficient in situ observations to validate them, it is difficult to justify the assumptions in ice particle size distributions in the calculations. However, the simple model retrieval in this study provides a unique way to demonstrate the large regional variations of the ice particle properties near the top of deep convection. It is also important to note that the simple retrievals also confirm the relationship between the strength of convection and size of ice particles.

\section{Discussion and summary}

Using the GPM precipitation feature database and measured radar reflectivity datasets from April 2014 to March 2017, we have defined deep convective cores in individual precipitation systems. Using $\mathrm{Ku}$-band and
Ka-band reflectivities, dual-frequency ratio profiles are calculated for deep convective cores. Further, combining with the output of a radar simulator package, microphysical parameters are estimated from the dual-frequency radars measured reflectivities. Both DFR and derived microphysical parameters in DCCs reveal significant regional variations in the tropics and subtropics. For the first time, we are able to demonstrate these regional variations with spaceborne dual-frequency radars.

It is found that the DFR near the top of the deep convective cores (e.g., $12 \mathrm{~km}$ ) is positively related to the convective intensity. DFR of DCCs over subtropical land have higher values at $12 \mathrm{~km}$ and $25-\mathrm{dB} Z$ echo-top heights than tropical land and those over ocean. The highest values of DFR are found over the hot spots with the most intense convection. Ice microphysical properties in the upper level of DCC, including mean diameter, total ice particle number, and ice water content, are derived by applying the lookup tables to dualfrequency radar observations. The retrieved results show a larger mean diameter, more ice water content, and less ice particle concentration over land than over ocean near the top of the convective cores above $10 \mathrm{~km}$. 

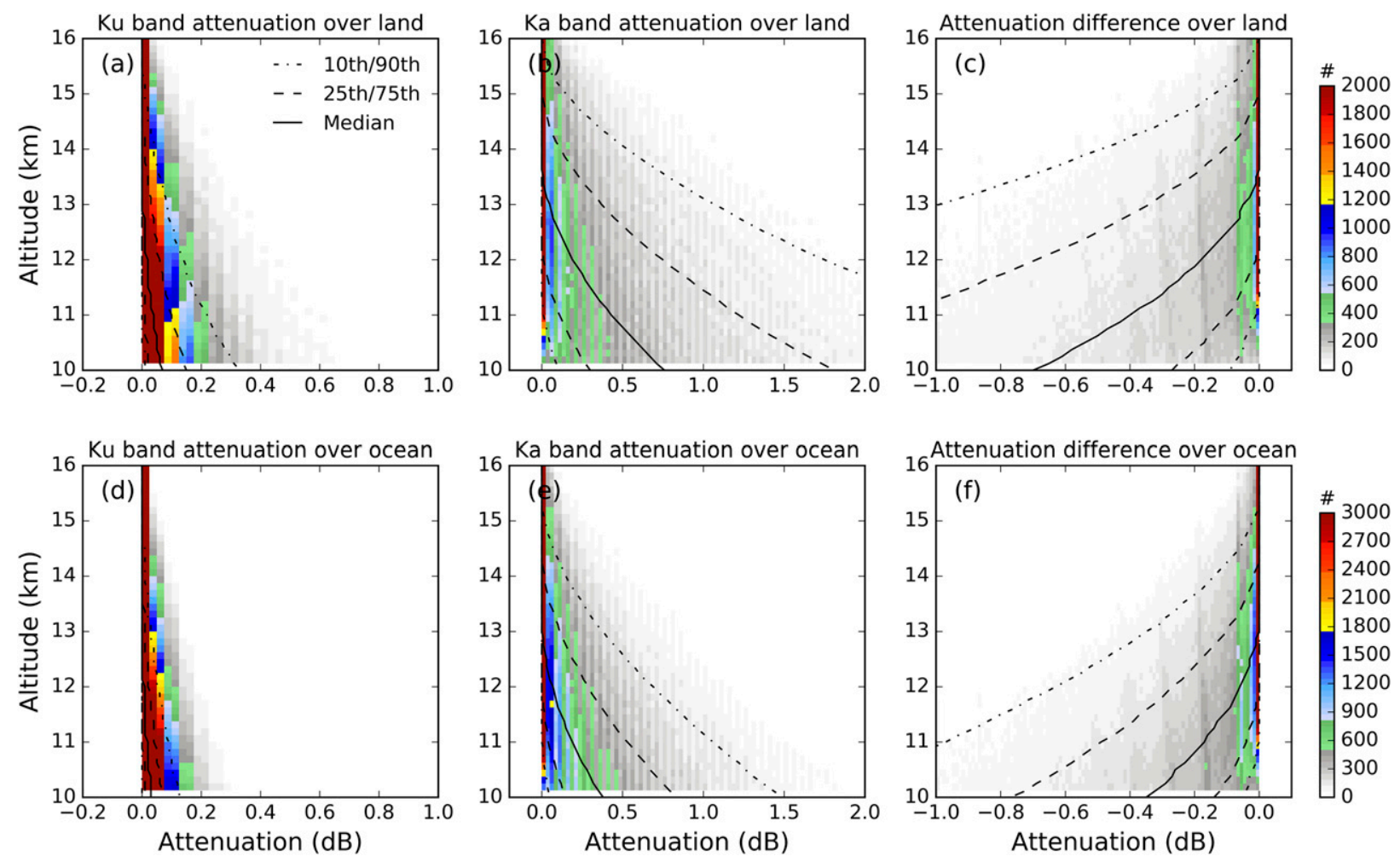

FIG. 13. The path-integrated attenuation estimated based on the retrieved ice particle size distributions. (a) Attenuation at Ku band over land. (b) Attenuation at Ka band over land. (c) Attenuation difference between Ku and Ka band over land. (d)-(f) As in (a)-(d), but for over ocean.

Meanwhile, five continental regions and four oceanic regions show distinct regional variations.

Overall, although the results of spatial distribution patterns and vertical microphysics structures are consistent with previous research, the simple model estimates of ice particle properties may still be far from reality due to assumptions of size distribution, attenuation, ice particle shape, and measurement accuracy. Future work is still needed to reduce bias in the retrievals, such as a better ice microphysics model to simulate the observables, and a longer database from GPM to build more robust statistics. Especially, more in situ observations of ice microphysics are critically required to validate the ice models.

Acknowledgments. Thanks to Joseph Turk and two anonymous reviewers for valuable suggestions to improve the quality of this work. This research was supported by NASA Precipitation Measurement Mission Grants NNX16AD76G and NNX16AH74G under the direction of Dr. Ramesh Kakar and also supported by Fundamental Research Funds for the Central Universities (SWU118132). Thanks also go to Dr. Erich Stocker and Patty McCaughey and the rest of the Precipitation
Processing System (PPS) team at NASA Goddard Space Flight Center, Greenbelt, Maryland, for data processing assistance.

\section{REFERENCES}

Battaglia, A., S. Tanelli, G. M. Heymsfield, and L. Tian, 2014: The dual wavelength ratio knee: A signature of multiple scattering in airborne Ku-Ka observations. J. Appl. Meteor. Climatol., 53, 1790-1808, https://doi.org/10.1175/JAMC-D-13-0341.1.

,,- K. Mroz, and F. Tridon, 2015: Multiple scattering in observations of the GPM Dual-Frequency Precipitation Radar: Evidence and impact on retrievals. J. Geophys. Res. Atmos., 120, 4090-4101, https://doi.org/10.1002/2014JD022866.

— , K. Mroz, S. Tanelli, F. Tridon, and P. E. Kirstetter, 2016: Multiple-scattering-induced "ghost echoes" in GPM DPR observations of a tornadic supercell. J. Appl. Meteor. Climatol., 55, 1653-1666, https://doi.org/10.1175/JAMCD-15-0136.1.

Carey, L. D., and S. A. Rutledge, 2000: The relationship between precipitation and lightning in tropical island convection: A C-band polarimetric radar study. Mon. Wea. Rev., 128, 2687-2710, https:// doi.org/10.1175/1520-0493(2000)128<2687:TRBPAL > 2.0.CO;2.

Cecil, D. J., 2009: Passive microwave brightness temperatures as proxies for hailstorms. J. Appl. Meteor. Climatol., 48, 1281-1286, https://doi.org/10.1175/2009JAMC2125.1.

_ , and C. B. Blankenship, 2012: Toward a global climatology of severe hailstorms as estimated by satellite passive microwave 
imagers. J. Climate, 25, 687-703, https://doi.org/10.1175/JCLID-11-00130.1.

Chandrasekar, V., H. Fukatsu, and K. Mubarak, 2003: Global mapping of attenuation at $\mathrm{Ku}$ - and Ka-band. IEEE Trans. Geosci. Remote Sens., 41, 2166-2176, https://doi.org/10.1109/ TGRS.2003.815973.

Christian, H. J., and Coauthors, 2003: Global frequency and distribution of lightning as observed from space by the Optical Transient Detector. J. Geophys. Res., 108, 4005, https://doi.org/ 10.1029/2002JD002347.

Fierro, A. O., J. Simpson, M. A. LeMone, J. M. Straka, and B. F. Smull, 2009: On how hot towers fuel the Hadley cell: An observational and modeling study of line-organized convection in the equatorial trough from TOGA COARE. J. Atmos. Sci., 66, 2730-2746, https://doi.org/10.1175/2009JAS3017.1.

Hamada, A., and Y. N. Takayabu, 2016: Improvements in detection of light precipitation with the Global Precipitation Measurement Dual-Frequency Precipitation Radar (GPM DPR). J. Atmos. Oceanic Technol., 33, 653-667, https://doi.org/10.1175/ JTECH-D-15-0097.1.

,$- \ldots$, C. Liu, and E. J. Zipser, 2015: Weak linkage between the heaviest rainfall and tallest storms. Nat. Commun., 6, 6213, https://doi.org/10.1038/ncomms 7213 .

Haynes, J. M., R. T. Marchand, Z. Luo, A. Bodas-Salcedo, and G. L. Stephens, 2007: A multipurpose radar simulation package: QuickBeam. Bull. Amer. Meteor. Soc., 88, 1723-1727, https://doi.org/10.1175/BAMS-88-11-1723.

Heymsfield, A. J., A. Bansemer, P. R. Field, S. L. Durden, J. L. Stith, J. E. Dye, W. Hall, and C. A. Grainger, 2002: Observations and parameterizations of particle size distributions in deep tropical cirrus and stratiform precipitating clouds: Results from in situ observations in TRMM field campaigns. J. Atmos. Sci., 59, 3457-3491, https://doi.org/10.1175/1520-0469(2002)059<3457: OAPOPS $>2.0 . \mathrm{CO} ; 2$

- C. Schmitt, A. Bansemer, and C. H. Twohy, 2010: Improved representation of ice particle masses based on observations in natural clouds. J. Atmos. Sci., 67, 3303-3318, https://doi.org/ 10.1175/2010JAS3507.1.

Heymsfield, G. M., L. Tian, A. J. Heymsfield, L. Li, and S. Guimond, 2010: Characteristics of deep tropical and subtropical convection from nadir-viewing high-altitude airborne Doppler radar. J. Atmos. Sci., 67, 285-308, https://doi.org/ 10.1175/2009JAS3132.1.

,-- L L. Li, M. Mclinden, and J. I. Cervantes, 2013: Airborne radar observations of severe hailstorms: Implications for future spaceborne radar. J. Appl. Meteor. Climatol., 52, 1851-1867, https://doi.org/10.1175/JAMC-D-12-0144.1.

Hou, A. Y., and Coauthors, 2014: The Global Precipitation Measurement Mission. Bull. Amer. Meteor. Soc., 95, 701-722, https:// doi.org/10.1175/BAMS-D-13-00164.1.

Houze, R. A., Jr., 1977: Structure and dynamics of a tropical squallline system. Mon. Wea. Rev., 105, 1540-1567, https://doi.org/ 10.1175/1520-0493(1977)105<1540:SADOAT>2.0.CO;2.

_ , 2004: Mesoscale convective systems. Rev. Geophys., 42, RG4003, https://doi.org/10.1029/2004RG000150.

—, K. L. Rasmussen, M. D. Zuluaga, and S. R. Brodzik, 2015: The variable nature of convection in the tropics and subtropics: A legacy of 16 years of the Tropical Rainfall Measuring Mission satellite. Rev. Geophys., 53, 994-1021, https://doi.org/10.1002/ 2015RG000488.

Jensen, M. P., and Coauthors, 2016: The Midlatitude Continental Convective Clouds Experiment (MC3E). Bull. Amer. Meteor. Soc., 97, 1667-1686, https://doi.org/10.1175/BAMS-D-1400228.1 .
Jiang, H., C. Liu, and E. J. Zipser, 2011: A TRMM-based tropical cyclone cloud and precipitation feature database. J. Appl. Meteor. Climatol., 50, 1255-1274, https://doi.org/10.1175/ 2011JAMC2662.1.

Johnson, R. H., 1984: Partitioning tropical heat and moisture budgets into cumulus and mesoscale components: Implications for cumulus parameterization. Mon. Wea. Rev., 112, 1590-1601, https://doi.org/10.1175/1520-0493(1984)112<1590: PTHAMB $>2.0 . \mathrm{CO} ; 2$.

Kuo, K.-S., and Coauthors, 2016: The microwave radiative properties of falling snow derived from nonspherical ice particle models. Part I: An extensive database of simulated pristine crystals and aggregate particles, and their scattering properties. J. Appl. Meteor. Climatol., 55, 691-708, https://doi.org/ 10.1175/JAMC-D-15-0130.1.

Le, M., and V. Chandrasekar, 2014: An algorithm for drop-size distribution retrieval from GPM Dual-Frequency Precipitation Radar. IEEE Trans. Geosci. Remote Sens., 52, 7170-7185, https://doi.org/10.1109/TGRS.2014.2308475.

—_, _ _ and S. Lim, 2009: Microphysical retrieval from DualFrequency GPM observations. 34th Conf. on Radar Meteorology, Williamsburg, VA, Amer. Meteor. Soc., P7.1, https://ams.confex.com/ams/34Radar/techprogram/paper_ 155196.htm.

Liao, L., and R. Meneghini, 2011: A study on the feasibility of dualwavelength radar for identification of hydrometeor phases. J. Appl. Meteor. Climatol., 50, 449-456, https://doi.org/10.1175/ 2010JAMC2499.1.

_ , and _ 2019: A modified dual-wavelength technique for $\mathrm{Ku}-$ and Ka-band radar rain retrieval. J. Appl. Meteor. Climatol., 58, 3-18, https://doi.org/10.1175/JAMC-D-18-0037.1.

,$- \ldots$, A. Tokay, and L. F. Bliven, 2016: Retrieval of snow properties for Ku- and Ka-band dual-frequency radar. J. Appl. Meteor. Climatol., 55, 1845-1858, https://doi.org/10.1175/ JAMC-D-15-0355.1.

Liu, C., and E. Zipser, 2013: Regional variation of morphology of organized convection in the tropics and subtropics. J. Geophys. Res. Atmos., 118, 453-466, https://doi.org/ 10.1029/2012JD018409.

— and most intense precipitation systems. Geophys. Res. Lett., 42, 3591-3595, https://doi.org/10.1002/2015GL063776.

,-- - , and S. W. Nesbitt, 2007: Global distribution of tropical deep convection: Different perspectives from TRMM infrared and radar data. J. Climate, 20, 489-503, https://doi.org/10.1175/ JCLI4023.1.

,-- D. J. Cecil, S. W. Nesbitt, and S. Sherwood, 2008: A cloud and precipitation feature database from nine years of TRMM observations. J. Appl. Meteor. Climatol., 47, 2712-2728, https:// doi.org/10.1175/2008JAMC1890.1.

_ S. Shige, Y. N. Takayabu, and E. Zipser, 2015: Latent heating contribution from precipitation systems with different sizes, depths, and intensities in the tropics. J. Climate, 28, 186-203, https://doi.org/10.1175/JCLI-D-14-00370.1.

Liu, N., and C. Liu, 2018: Synoptic environments and characteristics of convection reaching the tropopause over northeast China. Mon. Wea. Rev., 146, 745-759, https://doi.org/10.1175/ MWR-D-17-0245.1.

Luo, Y., R. Zhang, W. Qian, Z. Luo, and X. Hu, 2011: Intercomparison of deep convection over the Tibetan Plateau-Asian monsoon region and subtropical North America in boreal summer using CloudSat/CALIPSO data. J. Climate, 24, 2164-2177, https://doi.org/10.1175/2010JCLI4032.1. 
Matrosov, S. Y., A. J. Heymsfield, and Z. Wang, 2005: Dualfrequency radar ratio of nonspherical atmospheric hydrometeors. Geophys. Res. Lett., 32, L13816, https://doi.org/ 10.1029/2005GL023210.

Ni, X., C. Liu, D. J. Cecil, and Q. Zhang, 2017: On the detection of hail using satellite passive microwave radiometers and precipitation radar. J. Appl. Meteor. Climatol., 56, 2693-2709, https://doi.org/10.1175/JAMC-D-17-0065.1.

Olson, W. S., and Coauthors, 2016: The microwave radiative properties of falling snow derived from nonspherical ice particle models. Part II: Initial testing using radar, radiometer and in situ observations. J. Appl. Meteor. Climatol., 55, 709-722, https://doi.org/10.1175/JAMC-D-15-0131.1.

Petersen, W. A., and S. A. Rutledge, 2001: Regional variability in tropical convection: Observations from TRMM. J. Climate, 14, 3566-3586, https://doi.org/10.1175/1520-0442(2001)014<3566: RVITCO $>2.0 . \mathrm{CO} ; 2$.

Rasmussen, K. L., M. D. Zuluaga, and R. A. Houze, 2014: Severe convection and lightning in subtropical South America. Geophys. Res. Lett., 41, 7359-7366, https://doi.org/10.1002/2014GL061767.

Riehl, H., and J. S. Malkus, 1958: On the heat balance in the equatorial trough zone. Geophysica, 6, 503-538.

Rose, C. R., and V. Chandrasekar, 2006: A GPM dual-frequency retrieval algorithm: DSD profile-optimization method. J. Atmos. Oceanic Technol., 23, 1372-1383, https://doi.org/10.1175/ JTECH1921.1.

Sassen, K., Z. Wang, and D. Liu, 2009: Cirrus clouds and deep convection in the tropics: Insights from CALIPSO and CloudSat. J. Geophys. Res., 114, D00H06, https://doi.org/ 10.1029/2009JD011916.

Schumacher, C., M. H. Zhang, and P. E. Ciesielski, 2007: Heating structures of the TRMM field campaigns. J. Atmos. Sci., 64, 2593-2610, https://doi.org/10.1175/JAS3938.1.

Seto, S., T. Iguchi, and T. Oki, 2013: The basic performance of a precipitation retrieval algorithm for the Global Precipitation Measurement Mission's single/dual-frequency radar measurements. IEEE Trans. Geosci. Remote Sens., 51, 5239-5251, https://doi.org/10.1109/TGRS.2012.2231686.

Skofronick-Jackson, G., and Coauthors, 2017: The Global Precipitation Measurement (GPM) mission for science and society. Bull. Amer. Meteor. Soc., 98, 1679-1695, https:// doi.org/10.1175/BAMS-D-15-00306.1.

Smull, B. F., and R. A. Houze, 1985: A midlatitude squall line with a trailing region of stratiform rain: Radar and satellite observations. Mon. Wea. Rev., 113, 117-133, https://doi.org/ 10.1175/1520-0493(1985)113<0117:AMSLWA > 2.0.CO;2.

Sobel, A. H., S. E. Yuter, C. S. Bretherton, and G. N. Kiladis, 2004: Large-scale meteorology and deep convection during TRMM KWAJEX. Mon. Wea. Rev., 132, 422-444, https://doi.org/ 10.1175/1520-0493(2004)132<0422:LMADCD>2.0.CO;2.

Takahashi, H., and Z. J. Luo, 2014: Characterizing tropical overshooting deep convection from joint analysis of CloudSat and geostationary satellite observations. J. Geophys. Res. Atmos., 119, 112-121, https://doi.org/10.1002/2013JD020972.

Takayabu, Y. N., S. Shige, W. K. Tao, and N. Hirota, 2010: Shallow and deep latent heating modes over tropical oceans observed with TRMM PR spectral latent heating data. J. Climate, 23, 2030-2046, https://doi.org/10.1175/2009JCLI3110.1.
Toyoshima, K., H. Masunaga, and F. A. Furuzawa, 2015: Early evaluation of $\mathrm{Ku}$ - and Ka-band sensitivities for the Global Precipitation Measurement (GPM) Dual-Frequency Precipitation Radar (DPR). SOLA, 11, 14-17, https://doi.org/10.2151/ sola.2015-004.

Varble, A., and Coauthors, 2014: Evaluation of cloud-resolving and limited area model intercomparison simulations using TWP-ICE observations: 2. Precipitation microphysics. J. Geophys. Res. Atmos., 119, 13 919-13 945, https:// doi.org/10.1002/2013jd021372.

Wang, Z., G. M. Heymsfield, L. Li, and A. J. Heymsfield, 2005: Retrieving optically thick ice cloud microphysical properties by using airborne dual-wavelength radar measurements. J. Geophys. Res., 110, D19201, https://doi.org/10.1029/2005JD005969.

Williams, E. R., and G. Sátori, 2004: Lightning, thermodynamic and hydrological comparison of the two tropical continental chimneys. J. Atmos. Sol.-Terr. Phys., 66, 1213-1231, https:// doi.org/10.1016/j.jastp.2004.05.015.

Xu, W., and E. J. Zipser, 2012: Properties of deep convection in tropical continental, monsoon, and oceanic rainfall regimes. Geophys. Res. Lett., 39, L07802, https://doi.org/10.1029/ 2012 GL051242.

Yuan, J., and R. A. Houze Jr., 2010: Global variability of mesoscale convective system anvil structure from A-Train satellite data. J. Climate, 23, 5864-5888, https://doi.org/10.1175/ 2010JCLI3671.1.

Yuter, S. E., and R. A. Houze Jr., 1995a: Three-dimensional kinematic and microphysical evolution of Florida cumulonimbus. Part I: Spatial distribution of updrafts, downdrafts, and precipitation. Mon. Wea. Rev., 123, 1921-1940, https:// doi.org/10.1175/1520-0493(1995)123<1921:TDKAME> 2.0. CO;2.

, and $-1995 \mathrm{~b}$ : Three-dimensional kinematic and microphysical evolution of Florida cumulonimbus. Part II: Frequency distribution of vertical velocity, reflectivity, and differential reflectivity. Mon. Wea. Rev., 123, 1941-1963, https://doi.org/ 10.1175/1520-0493(1995)123<1941:TDKAME > 2.0.CO;2.

, and _- 1995c: Three-dimensional kinematic and microphysical evolution of Florida cumulonimbus. Part III: Vertical mass transport, mass divergence, and synthesis. Mon. Wea. Rev., 123, 1964-1983, https://doi.org/10.1175/1520-0493(1995) 123<1964:TDKAME $>2.0 . \mathrm{CO} ; 2$.

Zipser, E. J., 1977: Mesoscale and convective-scale downdrafts as distinct components of squall-line structure. Mon. Wea. Rev., 105, 1568-1589, https://doi.org/10.1175/1520-0493(1977) 105<1568:MACDAD>2.0.CO;2.

— , and K. R. Lutz, 1994: The vertical profile of radar reflectivity of convective cells: A strong indicator of storm intensity and lightning probability? Mon. Wea. Rev., 122, 1751-1759, https:// doi.org/10.1175/1520-0493(1994)122<1751: TVPORR $>2.0 . \mathrm{CO} ; 2$.

, D. J. Cecil, C. Liu, S. W. Nesbitt, and D. P. Yorty, 2006: Where are the most intense thunderstorms on Earth? Bull. Amer. Meteor. Soc., 87, 1057-1071, https://doi.org/10.1175/ BAMS-87-8-1057.

, and Coauthors, 2009: The Saharan air layer and the fate of African easterly waves-NASA's AMMA field study of tropical cyclogenesis Bull. Amer. Meteor. Soc., 90,1137-1156, https:// doi.org/10.1175/2009BAMS2728.1. 